\title{
The Pechenegs on the Territories of the States Neighbouring the Steppe
}

The migrations that took place under Kegenes and Tyrach ended the Pechenegs' existence as an independent ethnos living on the Black Sea steppe. The quality of the nomads' lives now depended largely on their relations with the rulers of the neighbouring states in which they sought shelter. These relations, in turn, depended on the size of the given Pecheneg group and the circumstances of their settling in the given state. The Byzantine Empire most likely took in the majority of the Pechenegs. A smaller but nevertheless visible number sought shelter in the Kingdom of Hungary and in Rus'. It is probable that some groups of Pechenegs reached Poland, but this is not well substantiated by source materials.

The sudden influx of nomads into the Byzantine Empire left the imperial administration with the difficult task of dealing with this migration. Byzantine policy towards the Pechenegs alternated between using violent force and attempting to peacefully integrate and assimilate them. Ultimately, Byzantine politicians opted to employ brutal force to resolve the Pecheneg question. With other states, the process of integration was much less tumultuous, but did not always lead to full acculturation. This was due not only to the aforementioned smaller number of Pecheneg migrants, but also to the fact that their migration was gradual and occurred over a fairly long period of time.

Apart from the Pecheneg groups that were incorporated into neighbouring states, some members most likely never left the Black Sea steppe. This hypothesis is based on the very nature of ethnic migrations, during which smaller groups often leave the main body of the ethnos. Such groups usually choose to stay in their current domain, even if this means submitting to a foreign power. As a result, they become incorporated into a new political body, lose their sovereignty, and usually disappear from written sources. It also cannot be ruled out that some groups of Pechenegs returned to the north bank of the Danube in the latter half of the 11th century. The history of the great migration in 1064 of the Uzes, who raided the Balkan provinces of the Byzantine Empire only to retreat from them a short time later, suggests it is possible that the same phenomenon occurred with the Pechenegs. In such a case, these smaller groups were most likely easily absorbed by other, stronger ethnic groups.

(C) ALEKSANDER PAROŃ AND INSTITUTE OF ARCHAEOLOGY AND ETHNOLOGY POLISH ACADEMY OF SCIENCES, 2021 | DOI:10.1163/9789004441095_009 
However, a number of researchers assume that after the migrations that took place under Kegenes and Tyrach, a fairly large and powerful group of Pechenegs remained on the Black Sea steppe and once again became an active force in the late 106os. The basis for such an assumption is data from Hungarian sources describing nomad raids on the Arpadian kingdom. Some contemporary researchers identify these nomads with the Pechenegs. They believe that the Pechenegs raided Hungary in 1068, 1071, and 1085. Moreover, researchers refer to data gathered by Anna Komnena on 'some Scythians' who crossed the Danube in 1086, as well as to the fact that John Kinnamos and Niketas Choniates mention the Battle of Beroia, fought in 1122 with 'the Scythians' by John Komnenos. Information from Hungarian and Byzantine sources will be discussed in detail in later parts of this chapter. At this point, it should be noted that this data is insufficient to support the thesis that there existed a fully sovereign and numerous group of Pechenegs on the Black Sea steppe and the north bank of the Danube after Tyrach's migration.

The late 1040s therefore represents a turning point in the history of the Pechenegs, i.e., the period during which they became part of the states neighbouring the steppe. It seems equally important that the Pechenegs, who were a nomadic people and heavily reliant on extensive herding, were forced to settle on lands whose natural conditions differed significantly from those of the Black Sea steppe. This initiated a process of change in their culture and associated social and political processes. In the case of the large Pecheneg communities in the Balkans, this situation also negatively affected their external relations within this new environment. As a result, the former inhabitants of the steppe proved to be a very troublesome partner for Byzantium.

\section{$7 \cdot 1$}

\section{The Pechenegs in Byzantium: 1047-1091}

\subsubsection{The Rebellion}

The solution applied to new subjects of the Empire by Constantine IX Monomachos and his administration, described in the previous chapter, was regarded as fully effective by Byzantine elites. An expression of this mood can be found in the writings of John Mauropous, bishop of Euchaita, who described events surrounding the arrival of the Pechenegs in the Balkans in a speech written after 21 April 1047. ${ }^{1}$ In it he described the nomads as savage barbarians lacking the intellectual, legal, and religious underpinnings of a proper social order. They were capable solely of organizing raids and seizing

1 Io.Maur., 142-147. On the dating of the speech: Lefort 1976, 265. 
anything that had legs as booty. ${ }^{2}$ However, the rhetorician was not the only one who depicted the nomads as a community sine rege et lege, resembling a pack of wild animals rather than human beings. Other Byzantine authors from the 11th century who described the Pechenegs presented them in a similar way. ${ }^{3}$ Mauropous referred to the same literary trope to emphasize the role of Providence, the actions of which had enabled the barbarians to rid themselves of their innate savagery and transform from animals to humans. This miraculous metamorphosis was of course complemented by their baptism. In short, the Pechenegs became part of the Roman nation because, according to the rhetorician, they gave themselves to it just like a river gives its waves to the sea. ${ }^{4}$ In this fervent confession of faith in the omnipotence of God, who is capable of turning the most savage barbarian into a civilized man, lay a firm conviction in the great power possessed by the Roman (Byzantine) cultural universe. When the Pechenegs crossed the borders of the Roman politeia, they entered an area under the influence of this cultural universe, so it was inevitable that they would succumb to its effects.

This conviction was real and not merely a rhetorical declaration. In the mid-1th century Byzantine elites momentarily held the mistaken belief that calling on the former steppe-dwellers to settle in the highland and upland areas between Serdica and Niš, areas that were certainly far from a promised land for them, ${ }^{5}$ and offering the nomad leaders a place among the Empire's elites would make the Pechenegs into loyal subjects. This line of reasoning was completely unrealistic and seems to show that the administration of Constantine IX clearly had no idea with whom they were dealing. The imposition of sudden, rapid cultural change on the Pechenegs simply made them more open to a call to rebel.

Such a call came very soon. ${ }^{6}$ In 1048, due to anticipated aggression by the Seljuq sultan, the Byzantine ruler decided to send 15,00o horsemen to

2 Io.Maur., $144\left(\S 9,196^{1}\right)$.

3 Cf. Malamut 1995, 122-123; Paroń 2011, 127-130; 2018, 226-233.

4 Io.Maur., 143-144 (§ 7-8), 145 (§ 12-13). Cf. Malamut 1995, 121.

5 Schmitt 2006, 480. The researcher assumes that when the Byzantines ordered the Pechenegs to settle in the highlands, they hoped that the steppe-dwellers would get used to the new conditions by shifting from 'vertical nomadism' to 'horizontal nomadism'. The latter meant that in summer, animals would graze in the mountains, whereas in winter they would return to the valleys.

6 For more on the Pecheneg rebellion and the war they waged with Byzantium in the years 1049-1053: Vasil'evskii 19o8, 15-24; Zlatarski 1934, 93-108; Diaconu 1970, 64-65, 73-76; Fine 1983, 209-210; Malamut 1995, 124-128; Stephenson 200o, 92-93; Spinei 2003, 135-136; Curta 2006, 296-297; Bonarek 2011, 76-86. 
Iberia. ${ }^{7}$ These forces were to be comprised of his newly acquired subjects. The Pechenegs were to be led by their former chiefs: Soutzoun, Selte, Karaman, and Kataleim, who had all been residing in Constantinople. The new units were well armed and their leaders were given valuable gifts by the emperor. The only Byzantine who is known to have accompanied the Pechenegs to the east was Constantine Hadrobalanos, a patrician who acted as their guide. ${ }^{8}$ The actions taken by Constantine IX seem to prove that the emperor and his administration trusted the Pechenegs and did not believe they would rebel. This is another point that gives us reason to believe that Byzantine politicians regarded the solutions adopted in the wake of the Pecheneg migration as fully effective. However, their hopes were quickly dashed. The troops sent against the Seljuqs managed to cross the Bosporus and advance a short distance to the east, but at that point, they stopped near Damatrys to deliberate amongst themselves. Some members of the group thought they should march on to Iberia in accordance with the emperor's orders, but the majority opted to either renounce their loyalty, seek shelter in the mountains of Bithynia and repel potential attacks from there, or to return to the Balkans and join the remainder of their ethnos. Ultimately, they were persuaded by Kataleim to choose the last solution, that is, to attempt to re-unify their ethnic group. The Pechenegs tried unsuccessfully to kill Hadrobalanos, who managed to escape and return to the court. ${ }^{9}$

Separated from Europe by the Bosporus, the nomads decided to swim across it. They reached the opposite bank of the strait near the Monastery of St. Tarasios, then headed undisturbed towards Serdica, where they joined forces with the local tribes and made contact with Pecheneg groups that had settled in other regions of the Balkans. Reunited and armed with axes, scythes, and other iron farming tools, they marched to Philippopolis, crossed the Balkan mountain range, and set up camp on the Osmos River, on the Danube plain. Selte and his men remained in Lobitzos (Lovech), but were forced to withdraw under pressure from troops led by Arianitzes, sent from the thema of Macedonia to deal with them. ${ }^{10}$

The Pechenegs eventually settled in an area that John Skylitzes called the

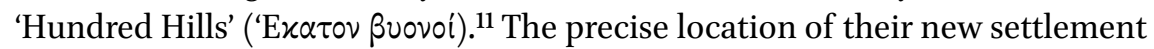
is not known. Some researchers assume it was located near Preslav, the former

Schmitt (2006, 481 (note 76$)$ ) believes that the number provided by John Skylitzes is too high and suggests lowering it radically to 1600-200o horsemen.

8 Io.Scyl., 46o (v. 87-97); Wortley 2010, 430.

9 Io.Scyl., 46o-461 (v. 3-18); Wortley 2010, 430-431; Io.Zon., 643; Trapp 1986, 106-107.

10 Io.Scyl., 461 (v. 18-42); Wortley 2010, 431-432; Io.Zon., 644; Trapp 1986, 107.

11 Io.Scyl., 465 (v. 29-34); Wortley 2010, 434-435.
} 
capital of Bulgaria. ${ }^{12}$ Others locate it somewhere in south Dobrudja or on the border between Dobrudja and north-east Bulgaria. ${ }^{13}$ Nevertheless, sources confirm that the 'Hundred Hills' contained valleys, groves, thickets, streams, and pastures. The presence of the latter seems to suggest that this new location, chosen by the Pechenegs themselves, suited their traditional lifestyle much better. They soon began to raid neighbouring lands, with the aim of their expedition being the area between the Balkan mountain range, the lower Danube, and the Black Sea coast.

The above events came as a complete surprise to Byzantine elites. The foundation of the Empire's policy towards the Pechenegs was turned upside down. Writing a few decades later, Michael Attaleiates, referred to it as trying to 'paint the Ethiopian white. ${ }^{14}$ While we can agree with him that the policy was inherently flawed had no chance of success, we need to note that more than one party was at fault, though the Byzantine author saw the situation otherwise. In reality, the Pechenegs were not so much offered living conditions they chose to reject, as much as ones they could never have accepted. This attempt to suddenly make a farmer out of a steppe-dweller, an individual accustomed to a nomadic lifestyle and the activities associated with it, made as much sense as trying to 'paint the Ethiopian white'. Michael Attaleiates understood his metaphor differently, however, and we can assume that he was disappointed mostly with the attitude of the Pecheneg elites. Byzantine authors of the time must have regarded the behaviour of Pecheneg leaders - who had received lavish attention from the emperor in terms of both their material and spiritual needs - as ungrateful. Yet, Constantine IX Monomachos had made a number of serious mistakes in his relations with the nomads.

Although the rebellion of 1048 posed a serious threat, the emperor still had means at his disposal that could potentially pacify it. It is worth noting that a large majority of Pecheneg leaders, including Tyrach himself, were in the hands of the Byzantines. They could be used as hostages to prevent the rebels from acting too violently, since without their leaders, the nomads would be much less dangerous. Moreover, at the outset of the rebellion, Constantine IX could still count on the loyalty of Kegenes and his men. They represented a minority of the ethnic group as a whole, but in the event of a war with the Pechenegs, an alliance with them would be a valuable asset, especially in view of Kegenes' military talents.

12 Angold 1997, 38; Curta 2006, 297; Schmitt 2006, 482; Madgearu 2013a, 213; 2013, 126 (to the north and east of Preslav).

13 Bromberg 1938, 9; Diaconu 1970, 66-69; Soustal 1991, 96; Spinei 2003, 135; Dudek 2007, 118.

14 Mich.Att., $54 / 55$. 
However, the emperor soon lost the support of Kegenes' men. When the nomad rebellion broke out, the Pecheneg leader had been summoned to Constantinople. He arrived with his troops and made camp near the capital, on a field called Maïtas. He never appeared before the monarch because he was attacked at night by three Pechenegs. The assassins managed only to cause him serious injuries and were quickly caught. When morning came, Baltzar, the older son of the injured leader, laid Kegenes down on a four-wheeled cart and entered the capital with the whole loyal troop. The three would-be murderers were chained to the carriage. Baltzar and Goulinos, the victim's second son, did not dare kill them because the assassins begged to be spared in the emperor's name. The result of their meeting with Constantine Monomachos led to a surprising result. When the monarch asked the assassins about their reasons for their attempt on Kegenes' life, they told him they did it because Kegenes had been critical of the emperor's rule and was going to enter the city at dawn to plunder it, murder its inhabitants, and join forces with the rebellious Pechenegs. The failed murderers turned out to be silver-tongued. Having believed their accusations, the emperor freed the assassins and imprisoned Kegenes and his sons. ${ }^{15}$

It is very probable the attackers were sent by the Pecheneg elites held in Constantinople, to whom Kegenes was a deadly threat. They most likely feared he would advise the emperor to put down the Pecheneg rebellion using means just as radical as those he proposed when the nomads had first arrived in the Balkans. And, in fact, murdering the elites would indeed have most probably made it easier to suppress the rebellion. Even if the Byzantines expressed moral reservations and refused to commit such brutal murder, Kegenes would still be very dangerous to Tyrach and the rest of the Pecheneg leaders. This was because he could either make use of the isolation of the elites to gain control over all Pechenegs or try to destroy them in cooperation with imperial troops.

The motives of the nomad elites are clear, but the behaviour of Constantine IX is more surprising, and must be considered a grave error. The emperor was clearly unnerved by what Kegenes' would-be murderers told him. He not only arrested Kegenes and his sons, but also attempted to neutralize their followers by ordering that their horses and weapons be taken from them and that they be imprisoned. However, the emperor's odd behaviour made the Pechenegs suspicious. They did not allow themselves be disarmed and withdrew from Constantinople under cover of darkness to cross the Balkan mountains and join the rest of the Pechenegs. ${ }^{16}$ In this way, Constantine Monomachos

\footnotetext{
15 Io.Scyl., 465-466 (v. 36-63); Wortley 2010, 435 .

16 Io.Scyl., 466 (v. 63-76); Wortley 2010, 435-436; Mich.Att., 54/55.
} 
strengthened the rebel forces and lost a valuable trump card that could have been used against them.

Meanwhile, the nomads, no longer threatened by Kegenes and his men, grew even bolder. They set up camp near Aulê, at the foot of the Balkans, not very far from Adrianople, and began carrying out plundering raids. Magistros Constantine Arianites, doux of the West, organized a military campaign against them. After defeating a few smaller Pecheneg units on his way to Dampolis (Yambol), he encountered the main body of their forces in the vicinity of the fortress. Arianites clearly underestimated his opponents. Even though his army was tired out from the long journey, he immediately engaged the nomads in battle and was defeated. Many soldiers from the themata of Thrace and Macedonia died in battle. Constantine Arianites himself sought shelter in Adrianople and from there sent word of the defeat to the emperor. ${ }^{17}$

Constantine IX appears to have been aware of the gravity of the situation, but he once again made a serious mistake. He attempted to placate the Pechenegs by releasing the elites being held in the capital, with Tyrach at their head, and lavishing them with gifts. In exchange, they promised to persuade their tribesmen to make peace. At the same time, however, perhaps due to doubts about the chances of this mission's success, he summoned the eastern tagmata (regiments) back to Europe and appointed rector Nikephoros as their commander. He also sent against the Pechenegs Katakalon Kekaumenos, doux of the East, and Hervé Frankopoulos, commander of the Latin mercenaries. ${ }^{18}$ The duplicity of the emperor's actions was obvious. Given the situation, Tyrach and the other released Pecheneg leaders had no choice but to warn their tribesmen about the approaching Byzantine army. ${ }^{19}$ In these circumstances, any attempt to encourage them to adopt a peaceful stance would be doomed to failure. Thus, if the Pecheneg elites had ever intended to keep their promise to the emperor, they were now forced to renege on it. In this way, the Byzantine emperor once again strengthened his opponents, this time on the eve of a major military confrontation.

Nikephoros, who was leading the main Byzantine army, crossed the Haemus through the Sidera Pass, reached Diakene, a village near the 'Hundred Hills', and set up camp, fortifying it with a strong palisade. The rector was very aggressive in his actions, as evidenced by his decision to move the theatre of war

17 Io.Scyl., 466-467 (v. 76-92); Wortley 2010, 436; Cat.Cec, 178/179 (v. 12-28). Genadii Litavrin identifies the battle described by Kekaumenos as the battle of Dampolis. For other hypotheses and discussion: Cat.Cec., note 256, 386-391.

18 Io.Scyl., 467 (v. 93-108 (8)); Wortley 2010, 436-437.

19 Io.Scyl., 468 (v. 19-22); Wortley 2010, 437. 
out beyond the Balkan mountains, to the area neighbouring the enemy's home base. Nikephoros was convinced he would achieve victory and went so far as to bring ropes and leather bands to tie up Pecheneg captives. Against the advice of Katakalon Kekaumenos, he put off engaging in battle because he believed that carrying out an attack prematurely, before the main forces of the enemy had gathered, would make it impossible to destroy the Pechenegs once and for all. Yet, when it finally came time to do battle, it was the Byzantines who suffered a crushing defeat. Rector Nikephoros and Frankopoulos fled the battlefield with most of their army. Kekaumenos and his small force resisted, but during fighting the commander was severely injured and taken captive. ${ }^{20}$ The Pechenegs did not pursue the fleeing forces; however, they acquired a handsome booty, because most of the goods from the Byzantine camp fell into their hands. ${ }^{21}$

After the two battles lost by the Byzantines in 1049, relations between the Pechenegs and the Empire were very much like they were before their mass migration. The only major difference was that the Pechenegs had previously lived outside the Empire's borders and Constantinople had an ally among them, namely Kegenes and his followers. Due to the grave errors committed by Constantine Monomachos, the divisions that once stood in the way of Pecheneg unity had now ceased to exist, and the nomads' social elites had been reassumed their former position. Encouraged by their previous successes, the Pechenegs began raiding the Byzantine provinces south of the Balkan mountains. This led the emperor to mobilize another army, led by the heteriarch Constantine. In the spring of 1050, he gathered his forces comprised of soldiers from both the western and eastern tagmata - in the area near Adrianople, where he established a camp surrounded by strong fortifications. The Pechenegs arrived in the area on 8 June, having crossed the mountain range. ${ }^{22}$ The previous actions of Constantine seem to confirm that he treated the Pechenegs as an enemy that undoubtedly needed to be countered. However, not all his subordinates agreed with him on this subject. While senior military officers were holding a meeting in the heteriarch's tent, Samuel Bourtzes, a patrician and commander of the infantry, left the fortifications with his troops and attacked the Pechenegs without waiting for the commander's signal. As a result, the entire army was drawn into a battle with the Pechenegs, as the remaining troops, though not fully readied, joined the fight to support the infantry. The Byzantines were ultimately defeated, but they did not suffer

\footnotetext{
$20 \quad$ For more information on the life of Kekaumenos, see Chapter 4.4 of the present book.

21 Io.Scyl., 467-469 (v. 8-19, 22-50); Wortley 2010, 437-438; Mich.Att., 56/57-58/59.

22 Io.Scyl., 469-470 (v. 6o-73); Wortley 2010, 438.
} 
great losses and withdrew back to their fortifications. However, several high ranking commanders, including patrician Michael Dokeianos and magistros Constantine Arianites, were killed. The Pechenegs, whose morale was lifted significantly, immediately attacked the fortifications. They successfully filled the outer trench with branches and stones, but the sudden death of Soultzous, one of their leaders, who was struck, along with his horse, by an arrow fired from a catapult, curbed their enthusiasm. Moreover, relief arrived from Adrianople in the form of 'the regiment of the Scholai' led by protospatharios Niketas Glabas. The Pechenegs soon withdrew when they heard that Bulgarian troops led by syncellus Basil were en route. ${ }^{23}$ The Byzantine army was thus saved from a total rout.

However, Macedonia and Thrace were no longer safe, and the Pechenegs continued to raid them with impunity. Their boldest raids brought them to the foreground of the capital. One of their units even reached as far as the area of Katasyrtai. ${ }^{24}$ Constantine Monomachos was therefore more pressed to act than ever before. He once again opted to play a tried-and-true trump card. He freed Kegenes, most probably hoping that he would manage to bring at least some nomads back on board, thereby weakening the threat they posed. ${ }^{25}$ In light of the Pechenegs' conflict with Constantinople and the fact that Tyrach and his supporters had regained control over all Pechenegs, this mission seems to have been a lost cause. It is hard to say what Kegenes himself expected. Perhaps as a true inhabitant of the steppe, he simply believed in his own charisma. He had survived a number of assassination attempts ordered by Tyrach, including the last treacherous incident just outside the walls of Constantinople. It also cannot be ruled out that in $105^{\circ}$ he had received the title of magistros and archon of Patzinacia. ${ }^{26}$ Preserved copies of seals with these titles come from this period. Kegenes would thus have been granted the right from the Byzantines to act as the sole leader of the Pechenegs. The 'only' thing he required to accomplish this goal was the approval of his tribesmen; however, instead they treated him like a dangerous renegade. In 1050 or 1051, Kegenes made contact with a group of his fellow tribesmen who promised to do whatever he requested.

\footnotetext{
23 Io.Scyl., 470-471 (v. 73-107 (7)); Wortley 2010, 438-439; Mich.Att., 58/59-6o/61.

24 Io.Scyl., 471-472 (v. 23-27); Wortley 2010, 439-440.

25 Io.Scyl., 471 (v. 14-17); Wortley 2010, 439.

26 Cf. Madgearu 2003, 51; 2013a, 211; 2013, 123. Madgearu points out that the title of magistros, which appears in Kegen's seals, was of higher rank than that of patrician. It can therefore be assumed that he was granted additional powers, greater than those he enjoyed immediately after entering imperial service.
} 
Believing their assurances, he went to meet them, but when he arrived, the Pechenegs murdered him and cut him up into pieces. ${ }^{27}$

The treachery and ignominious death of Kegenes were largely a consequence of the emperor's mistakes. However, luckily for himself, Constantine IX did not base his plans solely on the mission he had entrusted to the magistros and archon of Patzinacia. The emperor formed new armies, but this time, bearing in mind his previous experiences, he decided to change his strategy and tactics. The aim now was not to annihilate the enemy, but to limit raids on the provinces south of the Balkan Mountains. Imperial commanders were ordered to avoid battles with the enemy's main forces and instructed to attack smaller units that had arrived in Macedonia and Thrace to plunder these lands. ${ }^{28}$ Changes were also clearly visible in the means of fighting employed by the forces assembled by Monomachos. These which were meant to resemble those of the nomads, and to this end, he had brought 20,00o mounted archers from the east. Apart from this, he mobilized reinforcements comprised of Franks and Varangians. The patrician and ethnarch Bryennios was appointed commander of these forces. He brought his army to Adrianople, where his actions were limited to defending nearby villages against Pecheneg raids. Another patrician, Michael Akolouthos, was sent with orders similar to those given to Bryennios. Close cooperation between the two commanders resulted in two victories over the Pechenegs, one in Goloe and the other in Toplitzos, a fortress on the Euros River. In Kharioupolis, these commanders completely surprised a group of nomads who were looting the thema of Macedonia. Pecheneg raids did not stop after these military successes, but for the next two years they were less much bold. ${ }^{29}$

In 1053, most likely encouraged by his recent successes, Constantine IX decided to try to defeat his enemy once and for all. In order to accomplish this, he mobilized a great army comprised of the forces from both the east and west. Michael Akolouthos was appointed its commander. He entrusted Basil the syncellus with the task of commanding the Bulgarian troops. The two commanders then set out to confront the Pechenegs, who had chosen to seek shelter in the Great Preslav once they learned of the planned military expedition. They built a palisade around their camp, forcing the Byzantine army to lay siege, which proved ineffective. The imperial forces were now far from a secure

27 Io.Scyl., 472 (v. 35-37); Wortley 2010, 440.

28 Io.Scyl., 471 (v. 17-23); Wortley 2010, 440; Mich.Att., 6o/61-62/63. For more on the changes in the Byzantines' tactics after the defeats suffered in the years 1049-1050: Stephenson 2000, 92.

Io.Scyl., 472-473 (v. 38-63); Wortley 2010, 440-441; Mich.Att., 6o/61-62/63, 64/65. 
supply base, and soon began to suffer from a scarcity of provisions. These circumstances led the Byzantine leaders to jointly agree on the need to withdraw under cover of darkness. The Romans' plans did not go unnoticed, however, and this time Tyrach proved himself to be an extremely capable commander. He gathered a sizeable force to pursue the retreating Byzantines and blocked the routes across the mountain range. The retreat turned into a chaotic route. Many Romans were killed or taken captive, and Basil the syncellus was killed as well. ${ }^{30}$

Constantine Monomachos intended to organize another expedition, but when the Pechenegs came to him seeking peace, he entered into a thirty-year peace agreement with them. ${ }^{31}$ The provisions set forth in the agreement are not known. We can only assume that it legitimized the status quo, for which the nomads had fought hard. Ultimately, it was the Pechenegs who determined the place and conditions of their settling within the Empire, thereby shattering the unrealistic hopes harboured in Constantinople. The conditions forced upon the Pechenegs in 1047 as terms for living within the empire had made their rebellion inevitable. However, it would have been possible to pacify them at an early stage of their uprising if not for grave mistakes made by Constantine IX Monomachos. It could even be said that the manner in which he treated Kegenes and his followers made the emperor responsible for restoring unity among the Pechenegs. It is difficult to determine what were the reasons behind the poor judgement of the basileus. We can only speculate that his indecision was a consequence of rivalry between politicians or political parties that suggested either employing drastic measures against the nomads or opposed this idea and opted for more conciliatory solutions, ones that were more diplomatic than military. The incompetence of the Byzantine army is equally startling. The defeats of 1049 and 1050 can be explained by the fact that they underestimating their opponents, but the failure of the last expedition of 1053 comes as a real surprise; all the more so since the enemy did not try to disperse, which the nomads normally did, but instead decided to defend a fortified camp that the imperial forces failed to take. The war against the Pechenegs therefore revealed a crisis in the Byzantine army, one that would be further neglected by subsequent emperors. ${ }^{32}$

The humiliated empire had to accept the presence of the Pechenegs in the Balkans. For the next 40 years, the ethnos enjoyed almost total independence.

$30 \quad$ Io.Scyl., $475-476$ (v. 17-37); Wortley 2010, 443; Mich.Att., 64/65-68/69; Cat.Cec., 18o/1$182 / 3$ (v. 19-30, 1-6).

$31 \quad$ Io.Scyl., 476 (v. 37-43); Wortley 2010, 443; Mich.Att., 74/75-76/77.

32 Treadgold 1995, 39f. 
Some researchers point to similarities between the Pechenegs and the nomadic Bulgars of Turkic descent. Almost four centuries earlier, they invaded the Empire's territory and created an independent political entity whose centre may have been located in the same area where the Pechenegs later likewise chose to settle..$^{33}$ The analogies here are indeed striking, but it is worth noting there were significant differences as well. First, it would seem that the position of the Dulo clan, from which Asparukh and his successors descended, was much stronger than the that of Tyrach's clan or that of any other Pecheneg noble. In addition, the Bulgars already had a monarchical tradition dating back to the times of Kubrat's Great Bulgaria. ${ }^{34}$ Asparukh rose to become an absolute ruler mostly as a result of his successes on the battlefield in the fight against Byzantium. The position of Tyrach was never as strong. We see him as a leader mostly at times when the Pechenegs as a group were threatened. Yet he was always surrounded by a number of other tribal chiefs, indicating his power was limited. As we saw in Chapter 4, the Pechenegs, unlike the Bulgars, did not create a strongly hierarchical political structure, but comprised a relatively loose, segmented political organism. Nothing indicates that this changed when they settled in the Byzantine Empire. Even when some Pecheneg leader rose to such eminence that his existence was noted by Byzantine sources, no member of this tribe is ever credited with attaining the status of a ruler. It is worth noting one additional point. After the Bulgars arrived in the Balkans and defeated the army of Constantine IV, they immediately began organizing their state. Around its centre were located vassal Slavic tribes, which most likely serve as a sort of buffer. ${ }^{35}$ This type of social engineering, scrupulously recorded in Byzantine sources, clearly indicates that the Bulgars indeed became masters of the lands located north of the Balkan Mountains. Nothing like this ever occurred in the case of the Pechenegs. We definitely cannot say they ruled over the thema of Paristrion. Until the 1070s, the Byzantine Empire controlled the urban centres on the lower Danube and the west cost of the Black Sea. The indigenous population, which had to choose between the Byzantine administration and the menacing nomads, who had earlier proven how aggressive they could be, usually opted for the Empire. This choice was also facilitated by certain steps taken by Byzantium, such as granting regular subsidies and maintaining trade relations with native groups, as a means of strengthening their loyalty. ${ }^{36}$

33 Stephenson 1999, 45; Bonarek 2011, 93-94.

34 Cf. Chapter 2 of the present book.

35 Nic.Patr., 36, 23-26 (p. 9o/91); Th.Conf., 359 (v. 12-17); Mango, Scott 1997, 499. Cf. Beshevliev 1981, 179-181; 1984, 6o-61; Halperin 2007, 86; Ziemann 2007, 167-179; Paroń 2013, 238.

36 Cf. Stephenson 1999, 56; 2000, 93-96. 
The Pechenegs therefore did not have traditions that would allow them to follow the path chosen by the Danube Bulgars, which led towards the creation of a strong monarchical system. It indeed seems that throughout their presence in the Balkans, they never showed any ambitions of this sort. They were a difficult and unpredictable partner, but they were sufficiently powerful that efforts to annihilate them proved to be extremely difficult. At the same time, they never posed an existential threat to Byzantium, even if they were able to effectively undermine its security and efforts to maintain order in the Balkan provinces.

Byzantium was unable to rid itself of the Pechenegs, but nor could it ignore them. The Byzantine administration therefore undertook measures to appease the Pechenegs in the form of subsidies intended to curb their aggression. ${ }^{37}$ They were also occasionally mobilized by the Empire and took part in a number of military campaigns. It cannot be ruled out that some members of the Danube fortress guard were also recruited from the Pechenegs. ${ }^{38}$ It is difficult to say whether the Byzantines undertook missionary activity among the Pechenegs or merely settled for their formally adopting Christianity. It is confirmation, however, of an archbishopric in Dristra with five subordinate suffragan dioceses, indicating that conditions for missionary work among the Pechenegs were favourable. ${ }^{39}$

Thus, despite all the failures suffered in the years 1048-1053, Byzantium possessed an array of tools which could over time turn the nomads into loyal subjects. Financial benefits, long-term military service, and conversion to a new faith all clearly opened up a path for the Pechenegs' acculturation. However, this would take time; and time was something the empire, which found itself in an ever-deepening crisis, no longer had.

\subsubsection{Feigned Loyalty (1053-1072)}

Six years of relative peace with the Pechenegs suggested that most of the group's leaders accepted the agreement made with Constantine IX Monomachos, but in 1059, during the reign of Isaac Komnenos, the former steppe-dwellers rebelled once again..$^{40}$ Their moment of opportunity coincided with a conflict

37 Mich.Att., 76/77. Cf. Stephenson 1999, 46-47, 49.

38 Madgearu 1999, 442. This is ostensibly evidenced by a quiver and elements of a bow discovered in cities on the lower Danube (Garvăn and Nufăru). See also Madgearu 2013, 124-125.

39 Stephenson 1999, 56-57; 2000, 97.

40 For more about the events between 1053 and 1072: Vasil'evskii 1908, 25-33; Zlatarski 1972, 110-119; Diaconu 1970, 76-81; Fine 1983, 210-211; Malamut 1995, 128-129; Stephenson 
that broke out between the Byzantine Empire and the Kingdom of Hungary, ${ }^{41}$ the reasons for which are unknown. The chronological proximity between the conflict and the Pechenegs' rebellion suggests that opponents of the Byzantine Empire might have been involved. ${ }^{42}$ The rebellion did not lead to any significant battles; Isaac Komnenos promptly headed north with his troops. After reaching Sofia, he met with the Hungarian diplomats who came to negotiate the restoration of peace. The Empire's only opponents were the Pechenegs, but they soon lost interest in fighting. Most of their leaders submitted to the emperor's authority; only one of them, Selte, chose to continue fighting against the Empire. However, his decision led to failure, as his seat, located in an inaccessible site somewhere on the Lower Danube, was seized and destroyed. ${ }^{43}$

Although startling, these events can be seen as logical and predictable. The Pechenegs must have realized a fight against the Empire without the help of the Hungarians had no chance of success, especially in the view of Isaac Komnenos' quick intervention. Selte's reaction exposes the ethnos' weak leadership. Michael Psellos, whose accounts differ slightly from the data provided by other 11th-century authors, argues that the emperor sought to drive the nomads out beyond the Empire's borders. ${ }^{44}$ While it is difficult to determine whether this is true or not, the willingness with which Isaac Komnenos accepted the oath of allegiance made by the Pechenegs casts doubt on the veracity of Psellos' account. Returning to the events of the summer of 1059, it should be noted that the nomads were quite eager to cooperate with an enemy of the Empire. The fact that their declaration of loyalty to the emperor had been made under the threat of military action best illustrates the value and strength of this oath.

200o, 93-98; Spinei 2003, 137; 2009, 112-118; Curta 2006, 298-299; Bonarek 2011, 87-94; Madgearu 2013, 127-131.

41 Mich.Att., 120/121; Scyl.Cont., 106.

42 Vasil'evskii 1908, 25; Moravcsik 1970, 62-63; Shepard 1999, 69; Curta 2006, 298; Spinei 2009, 112; Madgearu 2013, 95, 127-129. Madgearu argues that the Hungarian invasion was a response to Byzantine provocations organized with the help of the Pechenegs. Taking other sources into consideration, this interpretation seems wrong. Madgearu, relying on the misinterpreted accounts of Michael Psellos, assumes that another migration of Pechenegs from across the Danube took place in 1059.

43 Mich.Att., 120/121-122/123 (Attaleiates argues that the authority over Selte's seat was transferred to the Byzantine strategos); Scyl.Cont., 106-107; Io.Zon., 671; Trapp 1986, 125. For a discussion on the location of Selte's seat: Madgearu 2013, 129.

44 Mich.Psell., VII 7o (p. 242); Sewter 1953, 243. This information is confirmed by Matthew of Edessa, who argues that Isaac Komnenos allegedly crossed the Danube during his campaign against the Pechenegs. Dostourian 1993, 9o. 
Despite this, the following five years saw relative peace in the Balkans. This ended in 1064, when the Pechenegs began their invasions once again. ${ }^{45}$ These are mentioned in historical sources, which suggests they were significant in scale, but there is no information about who led them or the regions invaded. ${ }^{46}$ Byzantine border defence forces fought with a fair degree of effectiveness, and managed to ward off the enemy repeatedly. Despite this, the Pechenegs were not defeated, while their raids were ultimately suspended as the result of peace agreements.

These conflicts were merely a prelude to the chaos that enveloped the Balkans in the autumn of $1064^{47}$ as a result of a major migration by the Uzes. The course of these events bore a resemblance to the mass migration of Tyrach's Pechenegs twenty years earlier, when an entire ethnos similarly forced its way onto the Empire's territory. ${ }^{48}$ After easily defeating the Byzantine forces guarding the border and imprisoning their commanders, Basil Apokapes and Nikephoros Botaneiates the Uzes could freely plunder the western provinces of the Balkans, including Illyria and the areas around Thessaloniki. Some Uze forces reached as far as the thema of Hellas. The strength and numbers of the Uzes completely paralyzed the Byzantine administration. Emperor Constantine $x$ Dukas did not believe it was possible to militarily defeat the Uzes, so he resorted to diplomacy. When this failed as well, he decided to flee the capital and escape the growing dissatisfaction of his subjects, taking refuge in Choirobakchoi, escorted by an entourage of 15 o people. ${ }^{49}$

This seemingly hopeless situation had an unexpected positive ending for the Empire: just as suddenly as the Uzes had appeared in the Balkans, they now began to retreat. The reason for this withdrawal may have been illnesses that decimated the Uzes, like the Pechenegs years earlier. Michael Attaleiates, who described these events in the greatest detail, also mentions the nomads suffered from famine, despite having plundered the Balkan provinces. It should be noted that most of the Uzes' military activity was concentrated in the

45 Mich.Att., 150/51.

46 It is possible that it was the Pechenegs, not the Uzes, who conquered and destroyed Pliska. Michael Attaleiates' account suggests that Uzes fought mainly in the west Balkans (see below). The Byzantine author also states that in 1064 fighting with the Pechenegs occurred in close vicinity to their lands, matching the location of Pliska. For a traditional approach: Madgearu 2013, 89, 130.

47 Alexandru Madgearu dates the Uzes' invasion to 1065, relying on the accounts of Matthew of Edessa. He does not explain, however, why he considers the frequently inaccurate chronology of this source as more important than Byzantine sources. Madgearu 2013, 69 (note 55), 89, 130.

48 Mich.Att., 150/51-152/53; Scyl.Cont., 113-114; Io.Zon., 678; Trapp 1986, 129.

49 Mich.Att., 152/53-154/155. 
Empire's western Balkan provinces. It is thus possible that the Uzes, used to life on the steppe, found this mostly mountainous terrain an unsuitable area for inhabitation. ${ }^{50}$ Those Uzes who did not make it as far as the north bank of the Danube were attacked by the Pechenegs and Bulgarians. The survivors of these attacks returned to Byzantine lands, where they were relocated to Macedonia with the expectation that the Empire would hire them as mercenaries in future military actions. ${ }^{51}$

The Pechenegs' response to the Uze invasion generally served the interests of the Empire. They destroyed a significant number of the aggressor's forces and were most likely one of the reasons why the Uzes decided to retreat across the Danube. Despite this fact, their actions should not be seen as a result of the influence of Byzantine diplomacy. The Pechenegs fought in their own interest, annihilating their long-time enemies, whose presence in the Balkans must have seemed particularly dangerous for them. ${ }^{52}$ Also, having the Uzes within the sphere of interest of Byzantine diplomacy could not have been welcomed by the nomads, as there was a risk that Constantinople would use them against the Pechenegs.

50 A. Madgearu (2013, 130), referring to archeological finds, assumes that the Uzes were active only in the thema of Paradunavon. During their invasion, they were said to have destroyed Garvăn, Oltina (both situated on the Danube) and Pliska, which, if possible, seem to be the first part of the raid, concluded by the defeat of the Byzantine army and the capturing of its leaders. Later on, the nomads headed west, probably in search of booty.

$5^{1} \quad$ Mich.Att., 154/5-156/7, 158/9; Scyl.Cont., 115; Io.Zon., 679; Trapp 1986, 13 o.

52 Madgearu $(2013,129)$ argues that "the finest Pechenegs" took part in the Uzes' invasion. He based this hypothesis on Michael Glykas' chronicles, mainly on the following passage:

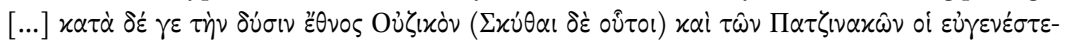

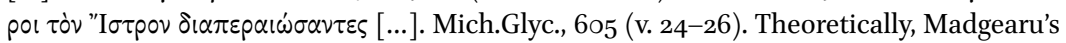
interpretation based on this passage is possible, although Glycas does not mention "the finest" Pechenegs but "nobler" ones. Therefore, the passage should be understood as: when the Byzantine Empire was struggling with the Turks on the east, "the Uzes" and "nobler Pechenegs crossed the Danube". The more accurate interpretation of Glycas' text

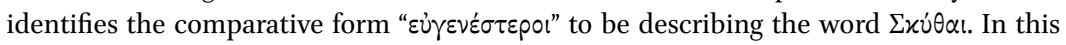
case, the above-mentioned passage should be understood in a different way: in the west, the Uzes, some Scythians nobler than the Pechenegs, crossed the Ister. The information provided by Glycas should be compared with the earlier accounts of the continuator of John Skylitzes' chronicle, who characterized the Uzes in the following way: $\tau \dot{\partial} \tau \hat{\omega} \nu$ Oü $\zeta \omega \nu$ हैقvos ( Scyl.Cont., 114 (v. 1-3). In the case of the second interpretation, the author wanted to emphasize the supremacy of the Uzes. Although they were Scythians, like the Pechenegs, they were nobler and more numerous. Therefore, there is no evidence of cooperation between the Pechenegs and the Uzes during the invasion of the Empire in 1064. 
After the Uzes' retreat, the Pechenegs no longer had any interest in remaining loyal to Byzantium. They attacked the Balkans again around 1066. According to the historical sources, their invasions were aimed solely at looting. It is hard to determine how far they reached into the Balkans. Romanos Diogenes, at that time a strategos stationed in Serdica, managed to stop them relatively quickly, defeating a large force of Pechenegs troops. As proof of his victory, he sent captives and the severed heads of the nomads killed back to Constantinople. As a reward, he was bestowed the title of vestarches ${ }^{53}$ by Emperor Constantine x Dukas.

The successes of Diogenes who would soon be crowned Emperor (1068), presaged the changes soon to come in relations between the Empire and its restive subjects. During the reign of the new basileus, the Empire cooperated militarily with the Pechenegs a number of times. They most certainly fought together against the Seljuks, and in 1068, they joined Diogenes during his campaign in Syria. They were also sent to requisition supplies in the vicinity of Aleppo and performed this task well, thoroughly plundering the enemy's land. They are said to have brought to the Roman camp numerous captives of both sexes and herds of cattle. ${ }^{54}$ One year later, mercenaries described as 'Scythians' again appeared with Romanos Diogenes in the east. Michael Attaleiates mentions them in his accounts of battles fought at Kaisareia in Kappadokia, where they were part of the advance guard of the Empire's army. ${ }^{55}$

'Scythians' also took part in the campaign of 1071, which ended with the battle of Manzikert. They were also responsible for foraging for supplies, such as when they were sent toward the fortress of Chliat. ${ }^{56}$ Their role before and during the battle of Manzikert is unknown. Michael Attaleiates mentions the desertion of one 'Scythian' unit led by Tamis, but this took place before the battle. ${ }^{57}$ This desertion induced the Byzantine Empire to ensure the remaining "Scythians" loyalty by introducing a special oath. Michael Attaleiates himself was responsible for performing this ceremony and, according to his account, it was sufficiently effective to keep all the 'Scythian' mercenaries on the battlefield. ${ }^{58}$ The fact that Attaleiates took part in these events would seem to give his account credibility, but we also need to remember that he was judging his own actions. Matthew of Edessa, a 12th-century Armenian chronicler,

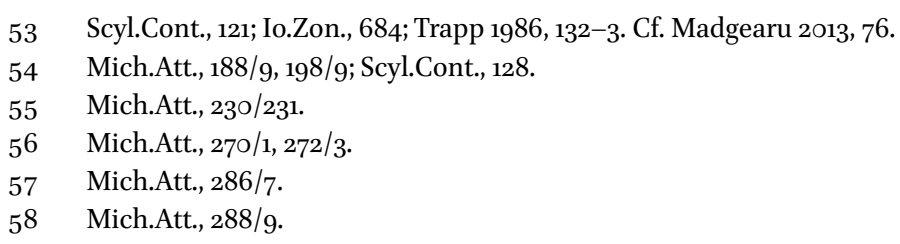


reported that Pecheneg and Uze troops on the right flank of Romanos Diogenes' army joined the sultan's forces during the battle. ${ }^{59}$ Although the information provided by this Armenian author is frequently distorted or untrue, in this case, his accounts can be trusted, considering his close geographical proximity to the events described. The nomads' betrayal was not as glaring as Matthew's brief account suggests. It may have resulted from the course of the battle; despite some early successes, the tide began to turn against the Imperial army. The desertion of the 'Scythian' mercenaries probably took place during this reversal of fortunes, as the Empire began to lose the battle. It is hard to accurately assess these actions, considering the dubious behaviour of some of the Byzantine commanders. ${ }^{60}$

In 1071, the Pechenegs took part in yet another military campaign on the Empire's north-west border. According to Hungarian chronicles, the Pechenegs moved onto the lands of the Arpad dynasty, where the forces of Belgrade made no effort at resistance. After crossing the Sava River, the Pechenegs devastated parts of the Kingdom of Hungary and then retreated with considerable booty and numerous captives. ${ }^{61}$ It is difficult to assess the role of the duke of Belgrade in provoking this invasion, but, Solomon, the King of Hungary, interpreted his actions as an act of aggression and organized a punitive expedition. The Byzantine fleet failed to stop the Hungarians on the Sava River, allowing Solomon and his army to reach Belgrade. The garrison defending the city called on the Pechenegs for assistance, but their forces were annihilated by the Hungarians. The few survivors fled the battlefield, including the Pecheneg leader Kazar. The Pechenegs' defeat sealed the fate of Belgrade's defenders, who surrendered after a three-month siege. ${ }^{62}$

The Byzantine provocation, if the Belgrade garrison had indeed played a role in it, grew into a serious border incident, adding to the state of chaos that had gripped the Empire since 1071. The Arpads took advantage of the Empire's growing troubles by attacking and conquering Niš. ${ }^{63}$ The tense situation in

59 Dostourian (1993), 135. The Armenian chronicler's information on the presence of the Pechenegs and the Uzes during the battle of Manzikert was confirmed by Ibn al-Athir: Richards 2002, 170. Cf. Bonarek 2011, 173.

6o On the second day of the battle, before its conclusion, Andronikos Dukas heard and began to spread rumours of Romanos Diogenes' death. Mich.Att., 292/293; Scyl.Cont., 148-149; Io.Zon., 701; Trapp 1986, 143. Cf. Angold 2008, 6o8; Korobeinikov 2008, 703; Bonarek 2011, 171 (note 854).

61 Chr.Hung., 369-370.

62 Chr.Hung., 370-374.

63 Chr.Hung., 377-378;Nic.Bryenn.,III 1(p.208/9-210/1). FormoreaboutByzantine-Hungarian relations between 1071 and 1075: Moravcsik 1970, 64-65; Shepard 1999, 71-79; Stephenson 200o, 141; Bonarek 2011, 104-105; Madgearu 2013, 96-98 (Madgearu assumes that as a 
the Balkans was further complicated by an uprising among the Slavs, led by Constantine Bodin, the son of Michael of Dioclea, ${ }^{64}$ though this rebellion was quickly crushed. The overthrow of Romanos Diogenes and crowning of Michael VII Dukas as emperor did not solve the country's problems. To the contrary, it provided the sultan with a pretext to continue his expansion in Asia Minor. ${ }^{65}$ The weakness of Byzantium also had an influence on its relations with the Pechenegs, whose became more brash in their actions. Shows of force, like the one carried out by Isaac Komnenos, and the later victories of the Byzantine emperors helped to keep the nomads in line and discouraged them from invading and plundering the Balkan provinces. An additional and probably equally important means of eliminating resistance were regular or occasional subsidies paid by the Byzantine administration as a kind of tribute to buy peace. A failure to make these payments carried the risk of sparking a rebellion.

The level of Pechenegs' loyalty between 1053 and 1071 was therefore relatively low. Their cooperation with the Byzantine army, mentioned in various historical sources, resulted from converging interests rather than loyalty to the Empire. The Pechenegs agreed to join the Empire in its military campaigns as long as they could benefit from them. However, another source of booty was their alliances with Constantinople's enemies and invasions of neighboring Byzantine provinces. Nothing suggests they had any ethical qualms that would have limited such actions.

Remaining within the borders of the Byzantine Empire should have led to the gradual acculturation of the Pechenegs. Such a process undoubtedly occurred. Although almost entirely independent, the former steppe-dwellers had to adjust to their new environment. These changes are especially visible in their funeral ceremonies. The ritual of burying warriors with their horses in prehistoric kurgans, typical of the Pechenegs from the Black Sea-Caspian steppe, disappeared in the Balkans. The influence of this ritual can still be seen in some graves, which contain elements of horse tack or even horse bones. ${ }^{66}$

result of the events of the early 107os the Empire maintained authority over Belgrade but lost Sirmium to the Arpads).

64 Eventually, he took the name of Peter, after the 1oth-century Bulgarian ruler and Peter Delian, the leader of the Slav rebellion of the 1040s. Cf. Stephenson 2000, 141-143; Madgearu 2013, 96.

65 Ostrogorski 1967, 283; Treadgold 1997, 604-6o7; Korobeinikov 2008, 702ff.; Bonarek 2o11, 190-195.

66 Fiedler 2013, 26o-267. After studying the available materials from the graves, the researcher notes that there are only six sites south of the Danube with inventories characteristic of steppe-dwellers, probably the Pechenegs. 
However, too few archeological finds of this sort have been made to allow for a more exact dating of such items or determination of their ethnic origin. Perhaps further research and the excavation of additional archeological material will help explain the nature of this sudden cultural change. The circumstances may have been prosaic, such as the decidedly poorer environmental conditions in the Balkans for the development of extensive herding, which in turn decreased the size of the nomads' herds of horses. Thus, as more valuable animals, horses were less frequently sacrificed during funeral ceremonies. ${ }^{67}$

A burial site discovered in Odărci (north-east Bulgaria) comprising $53^{6}$ graves $^{68}$ ostensibly provides evidence of rapid cultural change in the Pechenegs' social practices. Liudmila Doncheva-Petkova has dated this site to 1053. As evidenced from the crosses and encolpions found in these graves, the decline of steppe funeral ceremonies may also have been associated with Christianization. However, the assignment of this burial site to the Pechenegs has been called into doubt, particularly by Florin Curta. ${ }^{69}$ One of the main arguments supporting the hypothesis of its Pecheneg origins is the presence of elements of horse tack typical of steppe burial sites. However, in the Odărci burial site, the same elements were used for a different purpose: as clothing adornments. This raises the question of whether these ornaments were a means for the Pechenegs to demonstrate their identity in their new environment, as Doncheva-Petkova argues, or an adaptation of steppe traditions by a local, non-nomadic community, as suggested by Curta.

In an effort to combine both interpretations, one can argue that during the latter half of the 11th century, new communities came into being in the Balkans. They may have been comprised of a combination of nomadic, not necessarily Pecheneg, peoples and indigenous inhabitants. In his description of the revolt of the vestarches Nestor, Michael Attaleiates mentions the inhabitants of cities on the Lower Danube, calling them mixobarbaroi. ${ }^{70}$ It can be concluded from his account that their 'semi-barbarity' derived from linguistic diversity accompanied by - as I see it - cultural diversity. Most of these inhabitants were Christians, though loosely tied culturally to the Byzantine Empire. This Tower of Babel was also significantly influenced by nomadic communities. Attaleiates himself mentions that 'Scythians' imposed their traditions on, or simply them brought to, the Danube cities. This process is visible also in archeological finds which confirm that these cities were inhabited by people

\footnotetext{
67 Cf. general remarks: Lindner 1981, 3-19.

68 Doncheva-Petkova 2005; 2007, 643-66o.

69 Curta 2013, 170-178, 180-181. See also: Fiedler 2013, 270-271.

70 Mich.Att. 372/3-374/5. Cf. Bonarek 2007, 193-20o.
} 
with nomadic roots. ${ }^{71}$ On the other hand, the process may also have been reversed, meaning that nomads who had chosen to create settled communities may have adopted elements of the mixobarbaroi's culture.

Attaleiates clearly differentiates between 'semi-barbarians' and Pechenegs. The majority of the latter, residing in the Byzantine thema of Paristrion, probably had fewer contacts with the inhabitants of the cities of the lower Danube or cities along the Black Sea coast. Thus limited contact with foreign cultural patterns imposed upon their cultural universe to a much more limited degree.

The progressive Christianization of the Pechenegs is another matter worth considering. The available data, including that from both written and archeological sources, is too scarce to allow for a detailed examination. The finds from the Odărci burial site indicate that Christian funeral ceremonies were widespread. However, it has not been confirmed whether this site should be associated with the Pechenegs. Written sources provide almost no information about missions aimed at Christianizing these nomads. Outside of formulaic rhetorical praises, ${ }^{72}$ whose grounding in reality is uncertain, there are no clear indicators related to this topic. This is quite surprising, as it was the Christianization of the Pechenegs that made possible their 'Byzantinization'.

This cultural change, which most likely occurred around 1053, modestly strengthened the nomads' political loyalty to the Byzantine Empire. The events that accompanied this phenomenon presaged closer relations between the Pechenegs and some of the local communities described as mixobarbaroi, and perhaps even their integration.

\subsubsection{The Pechenegs and the Empire During the Crisis of the $1070 \mathrm{~s}$}

The year 1071, a dismal one for the Byzantine Empire, began a decade of crisis during which the Empire practically lost control over it lands north of the Balkans. ${ }^{73}$ Although there were still several enclaves controlled by Constantinople in the thema of Paristrion, especially in the north part of Dobrudja, ${ }^{74}$ the major part of the province had become independent of the

71 Cf. note 1583 .

72 An.Kom., VI 13.4 (p. 199); Sewter 2009, 182; La vie, 230. Both Anna Komnena and the author of The Life of St. Cyril praise emperor Alexios Komnenos. Cf. Stephenson 1999, $5^{6-57}$; Ivanov 2003, 224-247; 2008, 328-329. Ivanov suggests that the author's praises of the life of St. Cyril may be associated with the period after 1091, when the Pechenegs were subordinate to the Empire.

73 For general information on the events of the 1070s: Vasil'evskii 1908, 33-44; Zlatarski 1934, 154-166; Diaconu 1970, 100-111; Malamut 1995, 129-134; Stephenson 200o, 98-100; Spinei 2003, 137-140; Curta 2006, 299-300; Madgearu 2013, 131-132.

74 It is generally considered that north Dobrudja, especially the region of Isaccea, was loyal to the Empire. Confirmation of this loyalty is the functioning of a local mint. Madgearu 1999, 428; 2013, 82-83 (note 129); Curta 2006, 299. 
Empire. ${ }^{75}$ The reason for this was not only the Empire's military weakness, but also changes in Byzantine policy towards Paristrion's inhabitants, forced upon the Empire by a budgetary crisis. The eunuch Nikephoros, also nicknamed Nikephoritzes, the de facto ruler of the Empire at that time, ceased paying out subsidies to the Danube cities. As a result, some of them rebelled and allied themselves with the Pechenegs. ${ }^{76}$ Advisors to Emperor Michael viI sent Nestor, the katepano of the thema of Paradunavon, to the areas where the rebellion had broken out. He was considered to be loyal to the emperor because he had also served his father, Constantine $\mathrm{x}$. Before heading north, he was awarded the title of vestarches. ${ }^{77}$

Nestor's mission, which began in 1074, was diplomatic in character, rather than military. He traveled to the Danube cities along with several citizens of Dristra, whose role was to help him regain the loyalty of the city and the entire region. Once they arrived, Nestor quickly learned his task would not be easy. The city's inhabitants did not want to reinstate Constantinople's rule over them, and had instead entrusted authority over the Dristra fortress to a chief by the name of Tatus. ${ }^{78}$ His background is unclear; John Zonaras is the only Byzantine author who acknowledges him as a Pecheneg. ${ }^{79}$ Earlier sources provide no information about Tatus' ethnic origin, which suggests that the 12th-century chronicler determined it on the basis of his own speculations. The relation between the fortress's commander and the nomads, although well-established, does not constitute conclusive evidence of his Pecheneg origin. Tatus may have been a nomad or a descendant of nomads who decided to

75 Stephenson 1999, 58-6o; 2000, 98-100.

76 Mich.Att., $372 / 3-374 / 5$.

77 Mich.Att., 374/5; Scyl.Cont., 166; Io.Zon., 713, Trapp 1986, 15o. To learn more about Nestor's background and social status see Diaconu 1970, 103-104; Angold 1997, 121; Madgearu

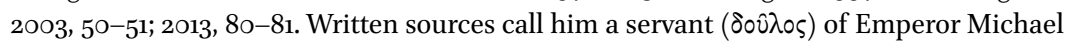

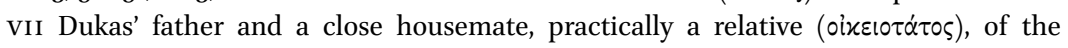
emperor. Sigillography confirms this data. Nestor was a servant of the Dukas dynasty. His background is unknown. Attaleiates argues that he was an Illyrian. This archaic ethnonym is sometimes related with Serbs or Vlachs. Madgearu presumes that Nestor may have been a local ruler in Duklja or Macedonia and transferred his authority to Constantine $\mathrm{x}$. Bulgarian researchers consistently recognize Nestor as a Bulgarian. Cf. Zlatarski 1934, 156; Tăpkova-Zaimova 1993, 99; Bozhilov, Giuzelev 1999, 405-406.

78 Mich.Att., 374/5; Scyl.Cont., 166; Io.Zon., 713, Trapp 1986, 15 o.

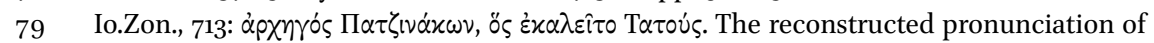
his name was *Tatu (Moravcsik 1983a, 302). Most researchers consider Zonaras' accounts reliable: Vasil'evskii 19o8, 34-35; Spinei 2003, 137; Curta 2006, 299; Dudek 2007a, 108; Madgearu 2013a, 216; 2013, 80, 82. The last author wrongly indicates Attaleiates as the author of the statement that Tatus was a Pecheneg. The fact that well-informed Attaleiates did not comment on the leader's background is telling. 
settle in the city. Michael Attaleiates' account on the 'Scythians' in the Danube cities supports this hypothesis, but at the same time, also excludes the possibility of Tatus being a Pecheneg leader.

Nestor, realizing that winning the loyalty of Dristra's citizens would be impossible, joined the rebels. His decision may have been based on the fact that logothete Nikephoros had confiscated his estate and property due to his alleged improper administration of Empire funds. ${ }^{80}$

In 1075, the rebels, now allied with the Pechenegs, invaded Macedonia. Their actions were so merciless that Byzantine troops quartered near Adrianople did not dare oppose them. Nestor and his allies passed through Thrace and destroyed the Byzantine camp in Byzas. After reaching the outskirts of Constantinople, the rebels demanded that the Empire surrender logothete Nikephoros as the cause of all their misfortunes. They promised to leave the capital promptly afterward. The emperor refused to pay heed to such demands, which, in view of the lack of adequate defensive preparations, could have resulted in the city's defeat. However, Nestor unexpectedly decided to leave Constantinople and retreat to the north. His decision was caused by his suspicions that a group of Pechenegs sent to the capital as emissaries were plotting to kill the rebel leader. ${ }^{81}$

Nestor's motivations are clear: he wanted to reclaim the property and position logothete Nikephoros had stripped from him. Eliminating the influential eunuch would not only allow him to regain both his property and dignity, it would also change the Empire's unpopular policy towards Paristrion. This would most likely been another of the former vestarche's goals, especially if he had the support of the Danube cities' citizenry. Nestor was not proclaimed emperor, but he seems never to have had any such ambitions. It is however possible that he hoped his close relations with the Dukas dynasty would allow him to easily regain the emperor's trust and persuade him into making decisions favourable to him. He may have also wanted to avoid a conflict with the emperor and shift the rebels' focus to the hated eunuch.

The Pechenegs played a significant role here. Nestor planned to use them to implement his political plans. This type of behaviour would soon become the modus operandi of a number of Byzantine politicians involved in the Balkans. According to Hungarian sources, the precedence for this goes back to 1071 and duke Niketas, the leader of Belgrade's garrison. The Pechenegs would become something like mercenaries whose payment would be the right to plunder the cities being attacked. Their loyalty to Byzantine allies was anything but

8o Mich.Att., 374/5-376/7; Scyl.Cont., 166; Io.Zon. 713; Trapp 1986, 15 o.

81 Mich.Att., 378/9-382/3; Scyl.Cont., 166; Io.Zon., 713-714, Trapp 1986, 15 o. 
strong. Nestor witnessed this first-hand when he was forced to retreat from Constantinople without achieving his goals.

The Pechenegs took advantage of the weakness of the Byzantine Empire by organizing plundering expeditions in Thrace and Macedonia. The decade of the 1070s was a golden age for the nomads, who were free to loot both of these Byzantine provinces. The Empire's military leaders rarely tried to repel their attacks. John Bryennios, brother of Nikephoros, the duke of Dyrrachion and pretender to the throne, ${ }^{82}$ routed groups of 'Scythians', most likely Pechenegs, a number of times. His final victory was in 1077 after his older brother had been proclaimed emperor. ${ }^{83}$ This success resulted in the Pechenegs becoming one of the usurper's allies.

It is difficult to determine the extent of Nikephoros' control over the Pechenegs. According to Michael Attaleiates, who expressed a clear dislike of Bryennios, a pretender to the throne, was almost their hostage. The nomads were said to have laid siege to Adrianople, the ancestral seat of the Bryennios clan, and threatened to attack the Macedonian emperor and his supporters. During the siege, the Pechenegs also methodically looted neighbouring areas, stealing herds of cattle. ${ }^{84}$ These events probably took place after the duke of Dyrrachion was proclaimed emperor, i.e., around the turn of 1077 and 1078. Nikephoros chose not to confront the enemy militarily, but instead took shelter in Adrianople and paid a handsome sum to convince the Pechenegs to end their siege: no less than 20 talents of gold and significant quantities of expensive fabric and silver dishware. ${ }^{85}$ A number of significant factors seem to explain the restrained, if not defeatist, stance taken by the imperial pretender. Nikephoros could not undertake any major military action against the Pechenegs so soon before he began his fight for the crown. This would have caused him to lose an uneasy ally and risk their attacking Thrace and Macedonia, which were among his bases of political support.

Although Bryennios' show of restraint saved his alliance with the nomads, the citizens of Adrianople were not provided with a long-lasting peace. In the summer of 1078, following the defeat of Bryennios and his allies, the Pechenegs laid siege to the city once again, this time assisted by the Cumans. They are said to have set fire to the houses outside the city walls, causing the deaths of numerous people. According to Michael Attaleiates, the reason for this attack was the murder by the citizens of Adrianople of the nomads' emissaries to

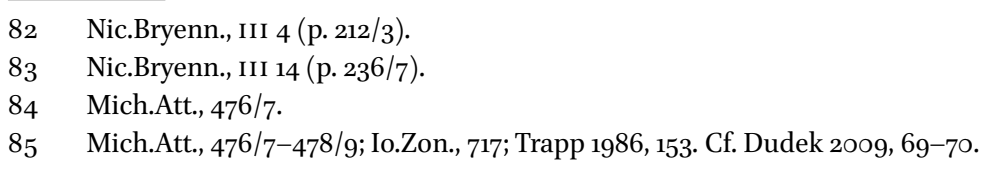


Bryennios. ${ }^{86}$ The circumstances surrounding these events remain unclear, but the alleged perpetrators clearly had just cause to feel hate towards the nomads, who after settling in the Balkans carried out numerous acts of aggression against the people living in the region. An interesting fact is that the Pechenegs did not take their revenge immediately. Instead they waited until the fall of Nikephoros Bryennios, perhaps because their urge for revenge was curbed by their alliance with the usurper.

In fact, the Pechenegs had been among those who supported him against Nikephoros Botaneiates during the battle of Galabrye ${ }^{87}$ (May 1078). The nomads showed little loyalty, however. All known accounts from the battle confirm their betrayal. The Pechenegs were ordered to make an attack from the rear on the men of Khoma, led by Constantine Katakalon. The nomads attacked the enemy, causing havoc and forcing Katakalon to retreat. However, instead of pursuing the scattered soldiers, they attacked the rearguard of Bryennios' army. After looting their allies' supply wagons and stealing their horses, they retreated to their own camp. 88

The Pechenegs shared a role in Bryennios' ultimate defeat, but this did not end the unrest in the Balkans. The new emperor, Nikephoros III Botaneiates was forced to suppress a rebellion led by Basilakes, the new duke of Dyrrachion. Like his predecessor Nikephoros Bryennios, Basilakes also tried to use the Pechenegs for his own purposes, but he too ended up achieving very little. At the same time the duke was under siege in Thessaloniki by the domestikos Alexios I Komnenos, the nomads, supported by the Cumans, were attacking Adrianople. As mentioned above, they set the city's outskirts ablaze, but retreated upon learning that Byzantine forces were approaching. 89

Near the end of the 1070s, the Pechenegs entered into an alliance against Nikephoros III Botaneiates with Lekas, a Byzantine renegade linked to the nomads by marriage. Lekas ultimately submitted to the emperor's authority, ${ }^{90}$ but this did not mean the nomads followed suit. Nikephoros Bryennios, the son or grandson of the unlucky pretender to the emperor's throne, mentions

86 Mich.Att., 348/9; Scyl.Cont., 184. Scylitzes Continuatus attributes the Pechenegs' death to Nikephoros Bryennios.

87 A town located in Thrace, $12 \mathrm{~km}$ north-west of Selymbria. Written sources and modern historical literature provide numerous variations of its name: Kalabrye, Galabrye, Kalobrye, Kalabria, Kalaure, Calavrytae, Kalavritai. Cf. Külzer 2008, 421-422; Dudek 2009, 70.

88 On the battle and the Pechenegs' involvement: Mich.Att., 528/9; Nic.Bryenn., IV 6-7, 9-13 (pp. 269-279); An.Komn., I 5-6 (pp. 20-27); Sewter 2009, 17-23. For a detailed analysis of the course of the battle: Tobias 1979, 193-211.

89 Mich.Att., 348/9; Scyl.Cont., 184 (v. 1-5); Io.Zon., 723; Trapp 1986, 156.

$90 \quad$ Mich.Att., 550/1; Scyl.Cont., 184 (v. 13-21). 
in his Material for History some 'Scythians' who devastated the lands between Niš and Scupi around 1079. ${ }^{91}$ Alexios Komnenos marched against them, but the nomads, upon receiving word of his forces' approach, retreated beyond the Balkan Mountains. In 1080, a campaign led by Leo Diabatenos momentarily pacified the Pechenegs and the Cumans, with both groups agreeing to enter into an alliance with the Empire. ${ }^{92}$

In terms of the relations between the Empire and its 'Scythian' subjects, the 1070s seems to have reflected a continuation of the status quo, rather than a turning point. The weakness of the Empire and the chaos it was struggling with provided the Pechenegs with additional freedom, and as a result, an increase in their attacks. Both Byzantine pretenders to the throne and renegades like Nestor and Lekas entered into alliances with the nomads, which to some extent legitimized their actions. However, the Pechenegs' loyalty to the Empire now was no weaker, nor stronger than during the two previous decades. It is difficult to assign any specific political aim to their actions. Their behavior was largely defined by external circumstances. Changes in these circumstances, like the consolidation of Nikephoros III Botaneiates' power and the stabilization of the political situation in the Balkans, encouraged the Pechenegs to keep the peace and enter into alliances with Constantinople.

As the influence of the Byzantine Empire declined, the Danube cities grew increasingly independent, resulting in important changes. The loss of support from Constantinople, meant that local leaders, backed by the surrounding population, assumed greater autonomy and authority. These leaders naturally sought to develop friendly relations with both the Pechenegs settled in Paristrion and the barbarian groups living north and north-east of the Lower Danube. The arrival of the Cumans in the Balkans, first noted in the summer of 1078, was therefore not accidental. Their participation in joint raids with the Pechenegs would not have been possible if not for the neutrality (or even cooperation) of the Danube cities' archons, who acted as intermediaries in contacts between these two nomad ethnic groups in the 1080s. ${ }^{93}$ We can assume that before this time they refrained from interfering in the affairs of the barbarian groups living on either sides of the Danube and made no efforts to impede their migration across the river. The independence of the Danube cities and their relations with the nomads led to the Empire losing control over Paristrion, which posed a danger to the rich Byzantine provinces south of the Balkans on the foreground of Constantinople. With the Danube no longer

$91 \quad$ Nic.Bryenn., IV 30 (p. 299).

92 Scyl.Cont., 185 (v. 21-23); Mich.Att., 550/1-552/3. Cf. Arutiunova 1972, 115.

93 Cf. the following part of the present chapter. 
serving as a barrier, the Pechenegs and other nomads from the north could easily use the Paristrion as a starting point to invade the Byzantine territories south of the Balkans.

\subsubsection{The Final Years (1081-1091)}

It was only a matter of time before the Byzantine political elite came to understand this fact. This moment most likely came when the former commander of the field army in the West, Alexios I Komnenos, ascended to power as emperor. ${ }^{94}$ Having worked at the side of Emperor Nikephoros III Botaneiates, the new basileus was well acquainted with the Pechenegs and their nature. He had fought with them several times in the late 1070s and understood that for the then badly truncated empire, the Pechenegs had become a serious threat. Following the loss of the entire Anatolian interior to the Seljuks, the Balkan provinces ${ }^{95}$ became the backbone of Byzantium. Anyone who violated the region's security would be essentially threatening the Empire's very existence.

Meanwhile, early in the reign of Alexios I, the Balkans had become the aim of expansion not only for the Pechenegs but for the Normans, as well. The latter were much more dangerous because there were not satisfied merely with pillaging, but also sought to bring Byzantium's territories under its rule permanently. Robert Guiscard, the Normans' leader, who in the ill-fated year of 1071 had conquered Bari and pushed the Empire out of southern Italy, ${ }^{96}$ made an initially successful attempt in 1082 to take over Byzantine Illyria by invading Dyrrachium. ${ }^{97}$ If this annexation had continued it would have been disastrous for the Empire because the Normans would have captured a key bridgehead at the beginning of the Roman Via Egnatia, the road leading towards Constantinople. The spread of their expansion along this important transport route would mean the end of Byzantium's rule over the Balkans, and probably the end of the Empire itself, as well. Alexios I therefore immediately took decisive action to counteract this threat.

As fierce battles were being fought over Dyrrachium, the Pechenegs chose to break the peace agreement they had concluded in 1080. Some time around

94 For a general description of the events of 1081-1091: Vasil'evskii 1908, 45-107; Zlatarski 1934, 182-208; Diaconu 1970, 112-120, 130-133; 1978, 35-40; Malamut 1995, 134-142; Stephenson 2000, 101-103; Spinei 2003, 140-145; Curta 2006, 300-302; Meško 2012, 121223; 2013, 197-205.

Ostrogorski 1967, 29o; Angold 1997, 129-130; Treadgold 1997, 614-615, 673-675; Lilie 2003, 331-335.

96 Cheynet 20o6a, 47; Bonarek 2011, 68-69.

97 An.Komn., I 16 (pp. 50-54), IV 1-8 (pp. 120-140); v 1 (pp. 141-143); Sewter 2009, 45-49, 108-130. Cf. Angold 1997, 130-131; Dudek 1999, 48-54; Cheynet 20o6a, 47. 
the end of 1083 , they crossed the Balkans to attack the Byzantine provinces. ${ }^{98}$ Pakourianos, the domestikos of the army of the West, managed to defeat them. However, his victory, mentioned in the typikon (rules) for the monastery he founded in Bačkovo, ${ }^{99}$ was not complete, as Pakourianos also mentions being held captive by the Cumans and being ransomed by the autocrator Alexios I. This unintended hint seems to prove that the victory of the domestikos over the Pechenegs was accompanied by a defeat suffered at the hands of the Cumans, though perhaps at a somewhat later time. This would mean that at the end of 1083 another joint invasion by both of these peoples may have taken place.

Pakourianos' success did not make a lasting impression on the Pechenegs, as we hear about plundering raids being carried out by them in the Balkans the very next year. This time, the Pechenegs allied themselves with a group of Paulicians who had rebelled against Alexios I. These heretics had lived in the vicinity of Philippopolis since the tenth century. Due to their great value in combat, they had been brought to this area to settle by John Tzimiskes, who gave them the task of defending Thrace against attacks by the Bulgarians. Seeking to expand his forces, Alexios I recruited 3,00o Paulicians, who had been part of the Byzantine army beaten by the Normans at Dyrrachium in October 1081. Later, however, the heretics failed to carry through on their promise to provide military assistance, thus earning the distrust of Alexios. The emperor decided to take preventive measures to safeguard the Empire against the Paulicians' rebellion. His decision stemmed from the location of the Paulicians seats, centred around Philippopolis, from which they could easily cut off the lines of communication linking the Balkan provinces with the capital. ${ }^{100}$ This posed a great danger to the whole of Byzantium. Alexios mustered the Paulicians under the guise of ordering a military inspection, then took them prisoner and ordered the community to be dispersed. The leaders were expelled from the Empire and the assets of the heretics were confiscated. ${ }^{101}$ This did not end the matter, however, because Traulos, a Paulician convert who had remained in

98 On the subject of dating these events: Arutiunova 1972, 118; Doimi de Frankopan 1996, 278-281; Stephenson 2000, 101.

99 Georg.Pak., 42/43; Jordan 2000, $5^{26}$.

100 An.Komn., V 3.2 (pp. 146-147); Sewter 2009, 133. Cf. Obolensky 1948, 19o; Stephenson 2000, 101.

101 An.Komn., VI 2 (pp. 170-171); Sewter 2009, 155-156. Cf. Obolensky 1948, 191; Angold 1997, 132. Some of the Paulicians remained, however, in the imperial service. They fought against the Pechenegs in the battle of Dristra. According to John Zonaras (Io.Zon. XVIII 23, p. 741) the Paulicians' tagma was to be disbanded only after the battle of Lebounion Hill (see below). 
the emperor's service since rising to the office of domestikos under Nikephoros Botaneiates, betrayed the emperor after learning about the fate of his former coreligionists. He then fled to Beliatova, a fortress north of Philippopolis. ${ }^{102}$

Traulos realized he could not accomplish much with the limited military resources at his disposal. He therefore formed an alliance with the Pechenegs and several independent chieftains who controlled fortresses on the Danube. The most powerful of these was the previously mentioned Tatus-Tatos, who ruled the city of Dristra. ${ }^{103}$ This alliance, in particular, posed a particularly serious threat to the interests of Constantinople. As a result, in the coming years successive waves of nomads would be able to cross the Danube unimpeded, intensifying the chaos in the Balkans.

The first of these groups appeared in the region around 1085. Anna Komnena, the only source to describe these events, mentions that 'some Scythian tribe'104 appeared on the Danube around that the time. The tribe had been forced to leave its former homelands under pressure from 'Sauromatians'. After reaching an agreement with the commanders of the border fortifications, they crossed the river and entered the territory of Paristrion. These newcomers first seized and pillaged several fortified towns. However, they then turned to more peaceful activities, and began cultivating the land, sowing millet and wheat.

The account of this migration provided by Anna Komnena is rather unclear, allowing for a number of plausible, but mutually exclusive interpretations. It is usually assumed that this event took place in 1086. However, if we take into account that the newcomers were said to have cultivated the land during breaks between plundering expeditions, and considering that earlier in the same year they defeated a military force dispatched by the empire, and were defeated by another, it seems more likely that their migration might have actually occurred in 1085. A more important issue, however, is the identity of the immigrants. They are most often identified as Pechenegs. This in turn has sometimes led to the conclusion, one generally lacking strong support in source materials, that a major group of steppe-dwellers lived north of the Danube long after the migration of Tyrach. ${ }^{105}$ Indeed, in Anna Komnena's narrative, the invasion of this

\footnotetext{
102 An.Komn.,VI 4.2-3 (p. 174); Sewter 2009, 158-159. Cf. Soustal 1991, 197.

103 An.Komn., VI 4.4 (p. 174); Sewter 2009, 159. Cf. Obolensky 1948, 191-192.

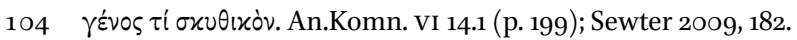

105 Meško 2012, 146; 2013, 182-187, 191-196. The researcher, following mainly the findings of Hungarian historians (most of all Ferenc Makk) brings the thesis about the presence of the Pechenegs north of the Danube to its extremes. Among other things, he admits that Kutesk, known to Hungarian sources, and Tzelgu, mentioned by Anna Komnena, were the leaders of two major Pecheneg groups, the first of which was said to be in Wallachia, and the second in Moldova. Apart from questionable interpretations of written sources,
} 
'Scythian tribe' is depicted as a turning point, and more precisely as the beginning of a series of events that led to an exhausting war between Byzantium and the Pechenegs, a war that would ultimately bring about the destruction of the latter. It is natural to identify these 'Scythian' newcomers with some Pecheneg fraction. Such reasoning seems all the more justified given that Komnena repeatedly substitutes their proper ethnonym with some archaic equivalent. On the other hand, it is hard not to notice that 'Scythians' is a very broad nomen collectivum that could refer to a variety of northern nomadic peoples. It can thus be used in cases when an author is unable to precisely determine or has difficulties defining the ethnic identity of the people under discussion. The learned princess seems to have found herself in such a situation in her account of the aforementioned migration. Possible evidence for this fact is her use of the indefinite pronoun 'some'. In 1085 or 1086, the Danube may have been crossed by a nomadic ethnos other than the Pechenegs, or a union composed of various ethnic fractions, including Pechenegs, that had once lived on the Black Sea steppe. In addition, there is no reason to assume this wave of migration was particularly large. It must have been considerable, since it was noted by Byzantine sources, but it was certainly not on the scale of the previous great migrations of the Pechenegs and Uzes. Byzantium reacted only when the newcomers, supported by Traulos and his Pecheneg allies, began to threaten the provinces south of the Balkans.

Alexios I sent an army led by domestikos of the West Gregorios Pakourianos against the aggressors. However, driven by excessive bravado, Pakourianos attacked an enemy force much larger than his own, resulting in the defeat of his army at Beliatova and his being killed in battle. ${ }^{106}$ A second army commanded by Tatikios managed to defeat the nomads by the Euros River (today the Maritsa) and regain the booty they had plundered. The Byzantine commander retreated with these acquired goods to Philippopolis. He soon left the city, as news reached him of the approach of another Pecheneg force. This time no battle ensued. After two days passed with neither party attacking the opposing forces, the nomads withdrew through Sidera Pass. ${ }^{107}$ The difficult year 1086 thus ended with limited success for the Byzantines. Although they

it is worth noting that Meško completely ignores archaeological materials that confirm the presence of nomads in Moldova, but at the same time shows that they barely left any traces in Wallachia. Diaconu 1970, 13, 39-49; Spinei 1986, 85-86; Ioniţă 2004, 469; 2005, 110-115; 2013, 115-150. For more moderate positions regarding the presence of the Pechenegs north of the Danube after 1050: Spinei 2003, 117-120; Curta 2006, 306. See also the part of the present chapter devoted to relations between the Pechenegs and Hungary. An.Komn., VI 14.3 (p. 200); Sewter 2009, 183.

107 An.Komn., VI 14. 4-7 (pp. 200-202); Sewter 2009, 183-185. 
managed to stop the Pechenegs from raiding of the themata located to the south of the Balkans unchecked. However, Tatikios's victories did not lead to a long-lasting peace.

In the spring of 1087 , the Danube was crossed by yet another group of nomads which, like the previous one, was composed of people of mixed ethnicity. Among the steppe-dwellers, there were probably Cumans, Pechenegs and Hungarians, all led by the latter group's dethroned king Solomon. The commander of this 'Scythian army', as Anna Komnena refers to them, was Tzelgu, whose ethnicity remains a mystery to this day. He was most likely a Cuman or a Pecheneg. Tzelgu and his army crossed the Balkans and invaded Thrace, where they conquered and plundered the city of Kharioupolis (today Hayrabolu). At Koule (a village located between Ainos and Constantinople), these 'Scythians' were intercepted and defeated by Byzantine troops under the command of Marianos Maurokatalon and Bempetziotes. Tzelgu was killed in battle and his nomad army withdrew to the Danube. ${ }^{108}$

The above-mentioned events during the years $1083^{-1087}$ followed a very similar pattern, according to which the Pechenegs repeatedly invaded the Empire's Balkan provinces, most often allied with other nomadic tribes (usually the Cumans) or supported by groups from within the empire that were at odds with Constantinople (such as the Paulicians). The position taken by the archons of the fortresses at crossing points on the Danube was also surprising, as they either responded passively to the steppe inhabitants entering the Paristrion area or actively cooperated with them. Yet these were not immigrants, but groups of aggressors for whom the Byzantine thema represented a transit zone leading towards the main objective of their armed expeditions the affluent regions south of the Balkans. Experience gained from this situation led the Byzantines to the conclusion that the more important provinces would not be safe until the Empire had regained control of Paristrion, and this would only happen after the Danube fortresses had been brought back under the control of Constantinople and the Pechenegs destroyed. ${ }^{109}$

In practice, this conclusion meant that Byzantium would have to undertake offensive actions in areas north of the Balkan Mountains. A military expedition of this sort had not been carried out by the imperial army since the time of Isaac I Komnenos, so it is hardly surprising that the decision of Emperor Alexios to send his troops into enemy territory was met with strong resistance from senior commanders. Ultimately, however, the opinion of younger

108 An.Komn., VII 1.1-2 (pp. 203-204); Sewter 2009, 186-187.

109 Cf. Ostrogorski 1967, 29o; Angold 1997, 130, 132; Stephenson 200o, 102. 
strategoi to confront the 'Scythians' in Paristrion prevailed.110 The late spring and summer of 1087 therefore represented a turning point in the history of warfare between the Pechenegs and Byzantium. The objectives of Alexios' campaign included both subduing the nomads and regaining control over the Danube fortresses. To this end, the emperor transported one part of the army under the command of Georgios Euphorbenos by boat to Dristra, while with the rest of the army was to march across the Balkans. ${ }^{11}$

Before the campaign had even begun, the Pechenegs tried to use diplomatic means to end it. They sent 150 emissaries to Alexios to propose a peace agreement that included a promise to supply 30,00o horsemen for the emperor's future military expeditions. ${ }^{112}$ This move by the Pechenegs' recalled their behaviour when dealing with Isaac Komnenos in 1059. In both cases the Pechenegs sought to avoid armed conflict merely by offering to place themselves formally under the emperor's authority. Bearing in mind his previous dealings with the Pechenegs, the Emperor knew that such declarations were of little value. Alexios thus used an anticipated partial solar eclipse, calling it a sign from God, as proof of the nomads' foul intentions and justification for his rejecting their offer. ${ }^{113}$ Afterward, he and his army crossed the Sidera Pass, and after a few days' march, reached the walls of Dristra with the intention of laying siege to the city. ${ }^{114}$ However, it soon turned out that he lacked sufficient forces to successfully take Dristra's two citadels. Ultimately, continually harassed by the Pechenegs, whose forces wiped out a number of raiding parties sent out to forage and succeeded in generating fear in the imperial camp, the emperor decided to take the advice of some of his commanders and force a decisive confrontation with the nomads. The battle ended in a major defeat for the Byzantines, with the emperor nearly losing his life. ${ }^{115}$ The imperial army was now in complete disarray, which meant the nomads would be free to ravage the Balkan provinces with impunity. However, they failed to make use of their great victory. The reason for this was the arrival of the Cumans, who had been called in by Tatos, the commander of the forces in Dristra, to support the Pechenegs in their fight against the Byzantine army. Despite their late arrival, they demanded a share of the spoils. When the victorious Pechenegs refused

\footnotetext{
110 An.Komn., VII 2.3,5 (pp. 205, 206); Sewter 2009, 188, 188-189.

111 An.Komn., VII 2.1-3 (pp. 204-205); Sewter 2009, 187-188.

112 An.Komn., VII 2.7 (p. 207); Sewter 2009, 189-19o.

113 An.Komn., VII 2.8 (pp. 207-208), Sewter 2009, 19o. This eclipse is usually dated to 1 August, 1087. Cf. Ferrari D’Occhieppo 1974, 179-184; Malamut 1995, 136; Dudek 2oo9, 246.

114 An.Komn., VII 3.1-2 (pp. 208-209); Sewter 2009, 190-191.

115 An.Komn., VII 3.3-12 (pp. 209-214); Sewter 2009, 191-196.
} 
to comply, the Cumans attacked their would-be allies and won. ${ }^{116}$ This clash is quite interesting because it illustrates a kind of hierarchy that existed between the peoples of the steppe. Michael Attaleiates described the Cumans as a 'most warlike nation'117 when writing about the invasion of Adrianople, which they carried out with the Pechenegs. This event, dated to the year 1078, gave rise to a whole series of joint plundering expeditions by these two ethne. The question then arises whether this refusal to divide the booty did not represent more than a mere rejection by the Pechenegs of an unjustified claim? Perhaps it also signified a breaking of the alliance between the two peoples. This assumption seems justified when we look at the later reports about the relations between the Pechenegs and Cumans, which after the incident of 1087 became distinctly negative in character.

For the moment, however, this rather unexpected course of events improved the already very difficult situation of Alexios I. After his defeat, the ruler took refuge in Beroia (today's Stara Zagora), from where he made an attempt to ransom Byzantine prisoners in order to incorporate them back into his army. Meanwhile, following their defeat by the Cumans, the Pechenegs moved their forces to the vicinity of Markellai (Markeli), where they set up camp. ${ }^{118}$ Their chose to encamp near the ruins of the fortress, so close to the former Bulgarian-Byzantine border, ${ }^{119}$ may indicate that their further plans involved setting out to plunder the Byzantine provinces. It is not impossible, however, that the nomads simply wanted to withdraw from regions threatened by Cuman attacks. Apart from the mention made by Anna Komnena, this last interpretation also seems to be confirmed by the Pechenegs' choice to move their encampments further south in the years that followed. Their concerns about the return of the Cumans were also shared by Alexios I Komnenos. This situation ultimately prompted both sides to make peace with one another, a move later praised in a speech by Archbishop Theophylact of Ohrid. ${ }^{120}$ The resulting peace treaty, which was most likely concluded late in 1087, lasted until spring of the following year, when the Pechenegs, realizing they were no

116 An.Komn., VII 5.1 (p. 216); Sewter 2009, 197-198.

117 Mich.Att., 348/9; Scyl.Cont., 184 (v. 1-5).

118 An.Komn. VII 6.1-2 (p. 218); Sewter 2009, 198-199.

119 The exact location of the Markellai fortress is under discussion. Most likely, it should be identified with the ruins of Hisarlŭk, near Karnobat, in today's Bulgaria. Its location indicates that its purpose was to safeguard the pass at the south-eastern edge of the Balkan Mountains. Swoboda 1967a, 179-180; Kazhdan 1991, 1300; Soustal 1991, 348-349.

120 An.Komn., VII 6.2-3 (pp. 218-219); Sewter 2009, 199-200; Theoph.Achr. 222-227. Theophylact's speech is dated 6 January, 1088. Malamut 1995, 138-140; Stephenson 2000, 102. For other dating, one year later: Dudek 2009, $25^{2}$. 
longer threatened by an invasion by the Cumans, nor by the possibility of these nomads forming an alliance with Byzantium, violated their agreement with the Empire. ${ }^{121}$

They did so by seizing Philippopolis. Alexios did not possess sufficient forces to oppose the nomads in an open fight, so he adopted hit-and-run tactics. Over the next year, he attempted to delay the opponent's march, prevent the capture of further strong points, and destroy smaller Pecheneg units whenever he could. When the two opposing armies reached Kypsella, south of Adrianople, the emperor sent out ambassadors to negotiate a truce with the nomads. They persuaded the Pechenegs to sign a new treaty, but it was quickly violated. In late 1088, the Pechenegs left Kypsella and seized Taurokomos, where they spent the winter. ${ }^{122}$ This was probably the first time in this people's history when a major part of the group wintered south of the Balkan Mountains. This seems to confirm the assumption that the Pechenegs sought to move their settlements southward.

When spring finally came, the Pechenegs resumed their military actions by marching on Kharioupolis. Alexios I sent against them a newly formed twothousand-strong unit of Arkhontopouloi, i.e., the sons of fallen soldiers. They were supposed to strike the Pechenegs' wagons from the rear, but instead of surprising the enemy they were ambushed themselves and suffered considerable losses. According to Anna Komnena, 300 young Byzantines were killed. After this success, the Pechenegs seized Kharioupolis and then headed towards Apros (between Rhaidestos and Malkara), plundering everything they encountered along the way. Wishing to prevent them from taking another city, the emperor's forces occupied them first. The unit commanded by Tatikios also managed to destroy one group of the Pechenegs that had been sent out at dawn to forage. ${ }^{123}$

This hit-and-run war probably continued throughout the year 1089 and even 1090 as well. Though he sought to avoid a decisive battle, Alexios tried to weaken his opponents' forces and restrict their room for manoeuvre. As the foreground of Constantinople, Thrace remained the primary area of operations. The Emperor fought the Pechenegs first in the area of Rousion (Tur. Keshan), and then at Tzouroulon, 36 kilometres away from the capital. Despite scoring victories in both battles, Alexios failed to achieve anything more than

121 An.Komn., vir 6.3 (pp. 218-219); Sewter 2009, 199-200. The Chronology of the PechenegByzantium war in the narrative of Anna Komnena is unclear, however, the winter of $1087 / 88$ probably brought a pause in their struggles, confirmed by the peace agreement that was broken in the spring of 1088. See Meško 2011, 145 .

122 AnKomn., vir 6.4-6 (pp. 219-220); Sewter 2009, 200-201. Cf. Meško 2011, 145.

123 An.Komn., VII 7.1-3 (pp. 220-221); Sewter 2009, 201-202. 
a temporary halt in the enemy's march on Constantinople, forcing them to retreat to the area between Little Nicaea and Boulgarophygon. The Pechenegs set up their encampments and spent the winter there. ${ }^{124}$

The spring of 1091 was to bring about a resolution to the situation. Nothing, however, indicated that the winner would be the Byzantine ruler. His situation had become nearly hopeless, as the nomads found a new ally in Tzakhas, the Emir of Smyrna. He was one of the Seljuk rulers who had received a share in the heritage of Suleiman, the first Sultan of Rum. Tzakhas had taken advantage of the weakened state of the Byzantine Empire in the 108os to expand his rule on the east coast of the Aegean Sea (including the cities of Klazomenai and Phocaea). He also assumed control over the islands of Lesbos, Samos and Chios. ${ }^{125} \mathrm{He}$ was able to do so thanks to a fleet built for him by a resident of Smyrna. ${ }^{126}$ It cannot be ruled out that Tzakhas had already established a partnership with the Pechenegs in 1090, ${ }^{127}$ but it was only early the following year that, through his envoys, he called on them to conquer the Thracian Chersonese (today the Galipoli peninsula). ${ }^{128}$ If such a military operation were successful, communication between Constantinople and the Aegean Sea would be cut off. The Emir of Smyrna would then be free to attack from the sea. Some scholars assume that he would have then been able to direct his expansion towards the eastern shores of Greece ${ }^{129}$ or, in an extremely unfavourable scenario for the Empire, even to attack Constantinople itself. Tzakhas, who had once been held as a prisoner-of-war in the court of Nikephoros Botaneiates, understood that the Empire's capital could only be successfully attacked from the sea. ${ }^{130}$ Having realized the intentions of the emir, Alexios Komnenos tried to prevent him from cooperating with the Pechenegs. To this end, he occupied and fortified the port of Ainos, located at the mouth of the Euros River. ${ }^{131}$ Maintaining control over this area allowed the basileus to prevent any communication between Tzakhas and the Pechenegs.

Alexios' situation was nevertheless still very difficult. His forces were not strong enough to defeat the Pechenegs, and his situation was further complicated soon after by the arrival of a Cuman army of 40,00o men, led by Togortak

\footnotetext{
124 An.Komn., VII 9-11 (pp. 227-235); Sewter 2009, 207-214. Cf. Meško 2011, 147.

125 An.Komn., viI 8.1-2 (pp. 222-223); Sewter 2009, 202-203. Cf. Cahen 1948, 52; Angold 1997, 133; Dudek 2007a, 120-122; Cheynet 2006a, 51.

126 An.Komn., VII 8.1 (p. 222); Sewter 2009, 202.

127 An.Kom., VII 8.6 (pp. 224-225); Sewter 2009, 204-205.

128 An.Komn., viII 3.2 (p. 241); Sewter 2009, 219-220.

129 Angold 1997, 133.

130 Ostrogorski 1967, 293; Runciman 1995, 77.

131 An.Komn., VIII 3.4-5 (p. 242); Sewter 2009, 220-221.
} 
and Maniak. Had the Cumans combined their forces with the Pechenegs, the Empire's defeat would have been certain. The emperor, however, managed to gain the support of the Cumans, secured with a pledge of loyalty and a number of hostages. ${ }^{132}$

The Pechenegs quickly realized the danger of such an alliance and endeavoured to have it broken. They sent envoys to Alexios with the intention of presenting him with peace proposals. The emperor held back his response, hoping to use the time spent in negotiations to increase his military potential. ${ }^{133}$ His previous experiences had convinced him that no peace treaty with the Pechenegs had any value. Anna Komnena wrote that the Pechenegs also simultaneously entered into secret negotiations with the Cumans. Despite their attempts at double-crossing 'diplomacy', they were unable to convince either side to break the agreement.

On 29 April 1091, the Pechenegs were forced to fight the allied armies on their own. The battle took place near the Lebounion Hill, on the left bank of the Euros River. It brought a final resolution to a war which had begun in 1083 . The extremely fierce battle lasted one day and ended with the defeat of the Pechenegs. Some of them died in battle, some were murdered by Byzantine soldiers afterwards, and others were sold into slavery. A large group of nomads, including the women and children, were ordered by Alexios I to settle in the thema of Moglena on the Vardar (Axios) River, entrusting them with the task of supplying light cavalry units. ${ }^{134}$

The result of the Battle of Lebounion was surprising, especially considering previous armed encounters between the Empire and the Pechenegs. This people - who not long ago had threatened the Empire's capital and managed to inflict a serious defeat on Alexios Komnenos - was now almost completely annihilated. The Byzantine soldiers and commanders participating in the battle had a similar impression, as can be seen in Anna Komnena's narrative. ${ }^{135}$ Admittedly, some scholars are inclined to assume that Alexios' victories were not as great as the learned princess seems to assert. ${ }^{136}$ Nevertheless, it is a fact

132 An.Komn., VIII 4.2-3 (pp. 243-244); Sewter 2009, 221-222.

133 An.Komn., VIII 5.1 (pp. 245-246); Sewter 2009, 223-224.

134 Io.Zon. XVIII 23 (p. 741), Trapp 1986, 167. Cf. Vasil'evskii 19o8, 107; Angold 1997, 133.

135 An.Komn., VIII 5.9 (p. 249); Sewter 2009, 226-227.

136 Macartney 1929, 350; Zlatarski 1934, 366-367 (The researcher admits that Lebounion was not as terrible a defeat for the Pechenegs as Anna Komnena describes it, because some of them survived on the Black Sea steppe. At the same time, however, he states that they lost their political independence in favour of the Cumans); Diaconu 1970, 133; 1978, 40 (Petre Diaconu represents a view similar to Vasil Zlatarski, however, he acknowledges that Lebounion meant the end of the threat of the Pechenegs to Byzantium). Cf. also argumentation described in the next paragraph of this chapter. 
that the Battle of Lebounion put an end to the existence of the Pechenegs as an independent ethnos.

\subsubsection{Epilogue: Beroia 1122}

In 1121, 30 years after this battle and in the fifth year of the reign of John II Komnenos, son of the victor at Lebounion, an event took place that cannot be omitted from a study devoted to the Pechenegs. ${ }^{137}$ According to the statements of John Kinnamos and Niketas Choniates, in this year a group of 'Scythians' crossed the Empire's border on the Danube. The first of these authors states that a massive force of nomads invaded Macedonia. John Komnenos went to face them, but all fighting had to be halted due to the approach of winter (1121/22). The basileus stopped at Beroia (Stara Zagora) and devoted all his free time to preparations for a spring campaign and diplomatic efforts aiming at disrupting the unity of the 'Scythians'. A battle took place in the spring of 1122, during which the army of the nomads was crushed. Some of the nomad soldiers, however, withdrew to their camp and fortified it by fastening wagons together and covering them with cowhides, in an effort to hold off the imperial army. The troops of John Komnenos had a hard time breaking through the "Scythians" defences. Only when the emperor sent Anglo-Saxon mercenaries armed with axes into the battle, did they managed to break through the nomad's defences and ultimately defeat them. The surviving prisoners-of-war were relocated within the Empire's territory as military settlers. ${ }^{138}$

John Kinnamos' account was confirmed by Niketas Choniates. In his highly sophisticated literary account of John II Komnenos' war with the 'Scythians', he adds only two pieces of information not noted by his predecessor. According to Choniates, the invaders occupied Thrace and ravaged the majority of Macedonia. Moreover, and much more importantly, after returning to the capital the emperor established a 'Pecheneg festival' ${ }^{139}$ to commemorate his victory over the 'Scythians'. This information became the basis for a quite common belief in modern scholarship that the mysterious nomads defeated at

\footnotetext{
137 The mentioned events are usually dated to 1121-1122. However, some researches admit that the events could have taken place one year later, in 1122-1123. Cf. Ivanov, Lubotsky 2010, 595-603.

138 Io.Cinn., I 3 (pp. 7-8); Brand 1976, 15-16. In his translation Charles M. Brand changes the name 'Scythians' to 'Pechenegs' without informing the reader about the original ethnonym.

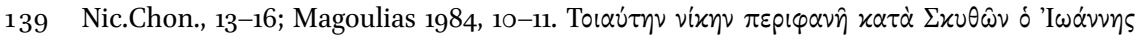

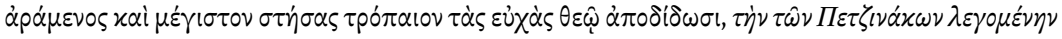

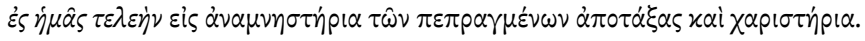


Beroia were, in fact, Pechenegs, or that they may have been an important, if not the major, part of an alliance of (ostensibly 'Scythian') nomads. ${ }^{140}$

Due to exceptionally fortunate circumstances, the events related to the invasion in 1121 and 1122 were noted not only by the above-mentioned Byzantine sources, but also by a number of authors belonging to completely independent literary traditions. The war with the 'Scythians' most likely represented an episode in an ethnic migration that was noted by neighbouring political powers on the Black Sea steppe. In addition, the Battle of Beroia and its circumstances were also described in a chronicle compiled by Michael the Syrian, Jacobite Patriarch of Antioch, in the twelfth century, who in turn relied on the knowledge of these events possessed by the Bishop of Edessa, a contemporary of Emperor John II Komnenos. This account in many respects corroborates the information provided by both Byzantine historians, but it also contains significant differences. Michael the Syrian recalls how cautiously the Empire dealt with the nomads marching on Constantinople. The Emperor wanted to make peace with them; however, when the nomads split up and began to enter cities, including Constantinople, and the emperor's very camp, he ordered them to be held captive, and he himself attacked their main camp. The siege of the steppe-dwellers' camp, which had been fortified with wagons, lasted several days. Ultimately, the Emperor ordered his troops to storm the defenders' positions. The camp was successfully taken, and many of the nomads were killed or taken captive. The most important element of the description provided by the Patriarch Michael, however, is the fact that the ethnos with whom the Byzantine Emperor fought was the Cumans. ${ }^{141}$ The credibility of this statement is questioned, mainly due to the lack of confirmation by other sources and the allegedly incorrect location of the battle site. These circumstances are said to also discredit his reference to the Cumans. ${ }^{142}$

140 Kurtz 1907, 86 (explicit identification of the invaders as the Pechengs); Rasovskii 1933, 18-19; Bibikov 1999, 199-228; Curta 2006, 312-314; Spinei 2003, 150-151; 2009, 126; Kozlov 2011, 14-15; 2014, 93-99.

141 Mich.Syr., XV 12 (pp. 206-207).

142 Kozlov 2011, 13. The researcher acknowledges that Michael the Syrian most likely meant the Pechenegs, whom he mistakenly called the Cumans, as he used the ethnonym to describe all nomadic peoples fighting against Byzantium. Apart from the fact that this reasoning does not prove anything, and only expands the circle of ethne that can be identified with the term 'Cumans', as described by the Syrian patriarch, it should be noted that Kozlov himself disavowed his argument, stating that there are very few, he claims, cases when Michael the Syrian correctly identified the nomadic enemies of the Empire (e.g., his mention of the expedition of Isaac Komnenos against the Pechenegs in 1059). 
On the other hand, some scholars take a much less critical stance towards the information contained in a work written in honour of John II Komnenos. ${ }^{143}$ Theodore Prodromos, the author of the epitaph, wrote it in the form of memoirs in which the deceased ruler spins a tale of his achievements, including his military successes. In speaking about his defeated enemies, John Komnenos mentions a 'western gathering of Getae' and the 'Scythian Chimera.' 144 These verses are supposed to be a reminiscence of the Battle of Beroia. They are also the basis for the thesis that the Uzes also took part in the battle. In Middle Byzantine literature, the Uzes appeared sporadically under the archaic ethnonym of Getae. ${ }^{145}$

The invasion of 1121/1122 was most likely a consequence of ethnic migration set in motion by the Rus' prince Vladimir Monomakh. The ruler initially welcomed refugees from the steppe and allowed them to settle in the territories under his control. According to accounts included in the chronicles, in 1121 Vladimir drove out the Berendei, while the Torks (Uzes) and Pechenegs 'fled of their own accord.'146 The chronological concurrence of this event with the invasion of the 'Scythians' under discussion here is indeed striking. These exiles were forced onto the Black Sea steppe, which was then controlled by the Cumans, and was thus an unwelcoming environment for them. In all likelihood, they then departed for the lower Danube. In this respect, Dmitrii Rasovski's nearly century-old interpretation remains relevant. ${ }^{147}$ All that needs to be changed is the incomprehensible and unjustified reluctance of some researchers to accept that when a group consisting of some or all of these refugees carried out raids on the Balkans, the Cumans were probably among them. As we have seen, starting in 1078 cooperation between this ethnos and the Pechenegs during raids is confirmed by Byzantine sources. There is also no significant reason to reject the information given by Michael the Syrian. On the contrary, it seems that the author pointed out the most important

\footnotetext{
143 Bibikov 1999, 207-212; Kozlov 2011, 15.

144 Prodromos, Xxv 35-37 (p. 336).

145 Moravcsik 1983a, 111.

146 According to the Primary Russian Chronicle, after the victories of Rus' princes over the Cumans in 1103 and 1116, a certain transfer of power over the groups of the Pechenegs and Torks (Uzes) could have taken place, as they fought on the side of the Cumans in both battles. PVL 1, AM 6611 (1103), col. 279: After winning the battle, the Rus' took over the camps (vezhe) of the Cumans, which were complete with livestock, possessions and servants, and 'took' (zaiasha) the Pechenegs and Torks along with their camps. Ip.Let., AM 6624 (1116), col. 284: after two days of fighting on the Don with the Cumans, the Pechenegs and Torks, the last two ethne, came to Vladimir's Rus'. Eventually, however, they left after the Berendeis were driven away: Ip.Let., AM 6629 (1121), col. 286.

Rasovskii 1933, 19. Cf. Kniaz'kii 2003, 77-78.
} 
and strongest of the ethnic groups that jointly attacked Byzantium in 1121 and $1122 .{ }^{148}$ John Komnenos' victory meant that some of these aggressors were pacified and settled within the Empire, but some probably retreated to the north. This is evidenced by information contained in the Chronicon Vindobonense, according to which, late in the reign of the Hungarian King Stephen II (circa 1124), a certain chief (dux) Tartar appeared in the region. He led a group of Cumans (Kuni), who after suffering defeat at the hands of an unspecified emperor, took refuge in Hungary. ${ }^{149}$ It seems that the only emperor capable of defeating the Cumans in the early 1120 s was John II Komnenos, and that defeat was the Battle of Beroia. 150

The 'Scythians' with whom Byzantium was involved in a war in 1121 and 1122 were not, therefore, a single ethnos, but a coalition composed of the Cumans and other steppe groups, probably including the Pechenegs, Uzes and Berendei. The mix of ethnicities in this group may explain the use of an archaic umbrella ethnonym. ${ }^{151}$ For Byzantine authors, the nomads were just various incarnations of a single people, well-known from classical literature. It was thus possible to use the archaic name 'Scythians' for each individual steppe ethnos, as well as for a confederation or even a temporary alliance of several ethnic groups. The ethnically diverse nature of the invaders also seems to be indicated by the wording used by Theodore Prodromos, who referred to a 'gathering of Getae' and the 'Scythian Chimera'.

148 Cf. Diaconu 1978, 62-71; Stephenson 2000, 106. Both researchers are certain that the invaders in 1121-1122 were Cumans.

149 Chr.Hung., 444-445; Joh.Thur., § 440 (p. 128). Cf. Vásáry 2005, 11 (note 38).

150 A distant echo of the Battle of Beroia is the story of the expedition of King Kirjalax (probably John II Komnenos) against Blokummanaland (Wallachia?) described in Heimskringla by Snorri Sturluson. In the area Snorri calls the Pecheneg Plains (Pezinovöllu), there was a battle involving the blind pagan king. Despite these mysterious names for the people and locations, much seems to indicate that this is probably a description of the Battle of Beroia. This is evidenced by Sturlusson's information about the course of the battle, which in its basic points corresponds to the accounts presented by John Kinnamos and Niketas Choniates. Similarly to the way it was described by the Greek historian, the pagans were supposed to surround themselves with a wall of wagons, and the victory of John's Varangian guards secured the victory for the Christians. Snorri also gives the name of the Scandinavian commander, Thórir Helsing. He claims that the attack by the emperor's personal guard was preceded by two unsuccessful attacks, the first by Greek troops and the second by Franco-Flemish units. Snorri, 787-788. Cf. Diaconu 1978, 72-77.

151 Michael Attaleiates probably did likewise when he described the expeditions of Roman Diogenes against the Seljuks. The author, who took part in those expeditions, mentions some 'Scythians' who were then a part of the emperor's army. These were most likely Uzes and Pechenegs, a fact of which Attaleiates was perfectly aware, though he still used an archaic umbrella ethnonym. See the above argument contained in the section 'Feigned Loyalty'. 
A separate, very interesting question is the reason why the name of the Pechenegs was mentioned in the narration of Niketas Choniates. It is worth noting that the author uses it only in the final fragment of the story about the war of 1121 and 1122 . The ethnonym was given as the name of the festival established by John II Komnenos, which clearly indicates that its use was intended by the monarch. Why, then, when establishing a festival in honour of a victory over a coalition of nomadic peoples, did he distinguish one of them in particular, and why one that most likely did not play a major role in it? It seems that we are dealing here with a conscious process of building the dynastic ideology of the Komnenoi by the Emperor. Members of this family line from Asia Minor, who managed to attain imperial power, are connected by their successes in battle with the Pechenegs. Isaac Komnenos brought them to heel and imposed on them his formal authority in 1059. His nephew, Alexios Komnenos, achieved a much more spectacular victory by practically destroying the Pechenegs at Lebounion. Later, in 1094, he also crushed the Cumans and restored the Empire's control over Paristrion, taking back the border on the lower Danube. ${ }^{152}$ John II, through the establishment of the 'festival of the Pechenegs', revalorized the victories of the older members of the Komnenos family, and pointed out that his triumph referred also to their successes, making the Emperor the true heir of the dynasty. ${ }^{153}$ The distinction of this particular ethnos was therefore not due to its special role in the events of 1121 and 1122. It was rather a kind of reference to the collective memory of the Byzantines, whose memory of exhausting struggles with the Pechenegs from 30 years ago was still vivid. Their invasions of the Empire's Balkan provinces created in the minds of the citizens of Byzantium, the image of a Pecheneg as the personification of all threats originating in the north, ${ }^{154}$ even though they were not the only people who plundered the provinces. The victory of Alexios Komnenos and the subsequent restoration of the Danube border seemed to put an end to the dangers coming from beyond it. The triumph of John Komnenos reminded everyone about old threats, but at the same time, it effectively eliminated them. The establishment of the 'festival of the Pechenegs' in all likelihood served to strengthen the image of the Komnenos dynasty as effective defenders of the Empire's borders. ${ }^{155}$

$15^{2}$ Diaconu 1978, 41-58; Stephenson 2000, 103-105.

153 In the aforementioned epitaph, Theodore Prodromos presents the figure of Alexios Komnenos, the persecutor ( $\left.\delta \iota^{\omega} \kappa \tau \eta \varsigma\right)$ of the Celts, Scythians and Persians. Prodromos, xxv 9-11 (p. 336).

154 Cf. Stephenson 2000, 106.

155 The epitaph of John Komnenos also contains a depiction of the lower Danube (Ister), and notes the Danube was navigable for imperial ships. The river was therefore not only a border, but also an area controlled by the ruler. Prodromos, XXv 41-42 (p. 337). 
The early relations between the Hungarians and Pechenegs were full of drama, with Magyar tribes being forced twice to leave their homes because of Pecheneg attacks. ${ }^{156}$ These conflicts, however, are poorly reflected in Hungarian sources. The only trace of them seems to be a legend written down in Hungarian chronicles that describes countless ravenous eagles devouring the cattle and horses of the Magyars after they crossed the Carpathians in their quest for a new homeland. Since the Old Turkic term for an eagle (becse) is very similar to the ethnonym used in Hungarian medieval sources to describe the Pechenegs (Bessi, Bisseni), it is sometimes assumed that the aforementioned legend is a distant reminiscence of battles fought between the two ethne in the late 9th century. ${ }^{157}$ The memory of the defeat suffered at that time and the fear of its perpetrators must have survived for some time among the Hungarians, but it did not result in eternal hostility, as evidenced by a joint raid on Byzantium that took place in $934 .{ }^{158}$ Hungarian sources, moreover, confirm that the Pechenegs settled in Arpadian Hungary relatively early. In the third quarter of the 1oth century, during the reign of Prince Taksony (d. 972), 'a knight from a ducal family' known as Thonuzoba is said to have come from 'the Pecheneg lands'. The ruler ordered him to settle in Kemey, on the left bank of the middle Tisza, in the place where the port of Obad was later built. ${ }^{159}$ Thonuzoba most probably did not come alone, but the long-standing claim put forward by Hungarian historiography that he brought with him one of the Pecheneg tribes $^{160}$ is unsubstantiated. In all probability, this group of refugees was not numerous. Moreover, this migration was relatively early, so the main Pecheneg settlements on the Black Sea steppe were not yet at risk. This leads us to believe no major influx of immigrants occurred at that time.

In the 1oth century, relations between the Hungarians and Pechenegs were relatively good. We have no information about armed conflicts being provoked

156 Cf. Chapter 3 of the present book.

157 Chr.Hung. 286; Joh.Thur., § 203 (p. 6o). Cf. Kristó 1996, 191.

158 Cf. Chapter 5 of the present book.

159 G.Ung., 116: Et in eodem tempore de terra Byssenorum venit quidam miles de ducali progenie, cuius nomen fuit Thonuzoba [...].

16o Fehér 1921-25, 136-139. Fehér assumes that the arrival of Thonuzoba was connected with

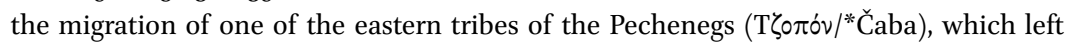
its settlements as early as in the 940s due to the threat posed by the Uzes and their raids. Aside from the fact that Fehér based his research on a number of assumptions which are difficult to prove, it should be noted that the dating of the threat posed by the Uzes, which supposedly caused the aforementioned migration, is much too early. Cf. Rasovskii, $5^{-7}$; Györffy 1990, 158, 187; 1971, 200; Göckenjan 1972, 96. 
by either party. The next century brought about a change, though not an especially radical one. As we have seen, the military activity of the Pechenegs on territories neighbouring the western fringe of the Black Sea steppe resulted from the fact that these nomads were gradually being forced out of lands east of the Dnieper. ${ }^{161}$ Apart from Byzantium, Transylvania may also have fallen prey to their raids. In The Life of Saint Stephen, there is mention of a Pecheneg raid that reached the vicinity of Alba Iulia (Alba Transsilvana). ${ }^{162}$ It is difficult to determine precisely when this raid took place. The nature of the sources which mention it makes it even harder to answer this question. One cannot help thinking that the authors of The Life of Saint Stephen referred to this event only to prove that Providence was taking special care of their devout ruler and his subjects. According to the story, King Stephen was warned in his sleep against an attack by the Pechenegs, who were approaching his land to loot the homes of his Christians subjects. He immediately sent to Transylvania a messenger who ordered the local people to seek shelter within the fortifications of Alba Iulia. We can assume that this raid, given that it was an actual historical event, took place during the long reign of Stephen I (997-1038). Any more specific dating would merely be speculation. György Györffy assumes the Pecheneg raid took place between 1015 and 1017 and had political undertones related to the rivalry between Poland and Hungary. Györffy suggests that supporters of Bolesław I the Brave used the Grand Prince of Rus' Sviatopolk as an intermediary to persuade the Pechenegs to attack the lands ruled by Stephen I. ${ }^{163}$ It is hard to confirm this hypothesis. Relations between Bolesław I the Brave and the Pechenegs, as we saw in the previous chapter, were not very friendly. Györffy also assumes that the nomad raid must have been inspired by some foreign power. This is a very stereotypical interpretation based on the notion that the nomads' only motivation was the desire to obtain rich booty, and that they were incapable of taking military action on their own. However, in this case, the reason for the Pecheneg raid was clearly looting, as noted in The Life of Saint Stephen. Therefore, there is no need to search for additional inspiration in the desires of outside forces to achieve their own goals. Romanian researchers, on the other hand, assume that the nomads raided Transylvania in 1028. ${ }^{164}$ This later date seems to be more convincingly linked with the increased activity

\footnotetext{
161 Cf. Chapter 6 of the present book.

162 Leg.St., 389, 423.

163 Györffy 1988, 169; 2003, 342; Zsoldos 2004, 126; Bárány 2012, 336.

164 Spinei 2009, 107. Spinei cites the chronicle of Heinrich von Mügeln, which mentions a raid by some Huns (Hewnen) who in 1028 invaded the country of the Bessers (this probably refers to the Pechenegs). Chr.Müg., 109-111. Despite its interesting chronology, this mention has nothing to do with the data in The Life of Saint Stephen.
} 
of the Pechenegs on the Lower Danube and in Moldavia, which indeed began in the second quarter of the 11th century. However, in this case as well, we are dealing with a hypothesis that is very difficult to verify.

Due to the turbulent events of the mid-11th century, most importantly the migration of the bulk of the Pechenegs to the Balkans, Arpadian Hungary no longer had to cope with looting raids organized by the Pechenegs. Some researchers assume that exactly 30 years after the death of Stephen I, i.e., during the reign of King Solomon (1063-1074), these raids started anew. This was when some nomadic group broke through border fortifications (indagines) in the vicinity of the upper Meszes, devastated the whole of the Nyír province, reaching as far as Bihar, a fortified city beyond the province's borders. The raiders collected a significant booty, namely, a great number of male and female captives, as well as cattle. During their return, they were cut off by an army commanded by King Solomon himself, accompanied by two princes, Ladislaus and Géza. The main battle took place by Kerlés Mountain, located in Transylvania, west of the city of Bistriţa. ${ }^{165}$ The battle ended in a decisive victory for the Hungarians.

Many researchers believe the Pechenegs were behind this raid. ${ }^{166}$ However, this interpretation raises doubts. Most importantly, it needs to be noted that Hungarian written sources are not unanimous in their verdict. Simon of Kéza, who mentioned events related to the Battle of Kerlés in his chronicle, regarded the opponents of the Hungarians to be the Pechenegs (Bessi), but his information about these events raises skepticism. This is in part because the chronicler dated the battle incorrectly and claimed it took place during the independent reign of King Ladislaus I (1077-1095). ${ }^{167}$

165 Near the east border of the former Szolnok-Doboka county. Cf. Göckenjan 1972, 97.

166 Györffy 199oa, 210-211; Göckenjan 1972, 97, 187 (note 9o); Makk 1999, 63; Spinei 2003, 130; 2009, 117-118; Curta 2006, 306; Meško 2013, 187; Berend, Urbańczyk, Wiszewski 2013, 232. Spinei cautiously takes the view that it was the Pechenegs who were behind the raid of 1068, but at the same time, cites a very interesting remark by a chronicler from west Rus', according to whom the Cumans and the Vlachs had organized a raid on Hungary which was repelled by Solomon and Géza. Moreover, the source explained that the Cumans were also called Polovtsy and Kum. The chronicler wrongly dated this incursion to 1059 . Russ.khr., 241.

167 Sim.Kéza, 182. It seems worth reflecting on the fact that the chronicler knew nothing about the Pecheneg raid of 1071, which was provoked by the duke of Belgrade. As we can recall, it was Solomon and both princes of the blood who headed the retaliatory action that led to capturing the Byzantine fortress. This gives grounds to the suspicion that Simon of Kéza merged the two raids and turned them into one event, which he dated to the reign of Ladislaus I. It seems that some medieval Hungarian authors took a dislike to Solomon, which could also explain the chronological shift made by the chronicler. Lastly, we need to note that in Hungarian sources, King Ladislaus appears as the slayer of all sorts 
Much more detailed information can be found in Hungarian Fourteenthcentury Chronicle Composition, according to which the raid of 1068 was organized by a ethnos called the Cuni. ${ }^{168}$ It should be emphasized here that this ethnonym does not appear anywhere in the work of Simon of Kéza. ${ }^{169}$ This brings to mind strong connotations with the Cumans. Nevertheless, this identification is challenged by contemporary scholarship. It is usually pointed out that in the Hungarian chronicles, the Latin term Cunus meant "somebody coming from the east, a horse rider, a nomad". ${ }^{170}$ In this case, it would have been a nomen collectivum whose range of meaning resembled Scythian, a category known from the Byzantine literary tradition. Until the mid-12th century, when Cunus was replaced by Comanus, this ethnic name could have referred to any nomadic tribe which bordered Arpadian Hungary to the east. However, even though the above interpretation does extend the scope of identification, it does not rule out the possibility of identifying Cuni with Cumans in this particular case. The Cumans had dominated the Black Sea steppe since the 1o6os, so they could have organized the raid on Hungary in 1068. It also needs to be noted that the Chronicle Composition, which describes two subsequent barbarian raids in 1068 and 1071, has its roots in the chronicling tradition which clearly distinguishes Cuni from Bisseni, i.e., the Pechenegs. According to this source, the latter raided Hungary three years after the Cuni.

Identifying the raiders of 1068 with the Pechenegs gives rise to other doubts unrelated to the quality of available sources. This includes the fact that this raid must have been organized by a very strong group living on the Black Sea steppe. The raiders first crossed the east Carpathians, then invaded Transylvania, engaging a large Hungarian force commanded by the King himself. These facts force us to consider the hypothesis that more than two decades after the migration led by Tyrach and four years after the wave of Uze migration, there still lived a very strong group of the Pechenegs in the western part of the Black

of nomads, which also gives grounds for an assumption that Solomon's successes were attributed to him because he had fought by his side.

168 Chr.Hun., 366-369; cf. Jo.Thur., § 335-341 (pp. 98-10o).

169 This silence seems telling, especially if we take into account the fact that Chronica Hungarorum mentions three such raids which took place in the 11th century, in 1068, 1083, and 1091. Chr.Hun. 366-369, 408-409, 412-414; cf. Jo.Thur., § 335-341 (pp. 98-100), § 395-396 (p. 115), § 400-403 (pp. 116-117). This state of affairs gives rise to an assumption that Simon of Kéza, chaplain of Ladislaus the Cuman (1272-129o), could have purposely left out information which would have shed a bad light on those who were close to the ruler or on influential Cuman settlers, who were numerous in Hungary.

170 Macartney 1940, 141 (note 1); Györffy 1990a, 215-216; Berend 2001, 190-191. Cf. Németh 1941-43, 95-107. The last researcher believes that the ethnonyms quman and qūn are synonymous and explains their meaning as 'fawn-coloured, yellow'. 
Sea steppe. They organized looting raids on Hungary, which seems to prove that their settlements on the steppe were not under any threat; otherwise in 1068 they would have tried to settle in Hungary, not just plunder it. However, this scenario seems rather improbable. Though it is indeed possible that long after Tyrach led the migration to the Balkans, small groups of the Pechenegs, either subordinate to the Cumans or part of some sort of ethnic conglomerate, lived between the steppe and the neighbouring countries. This is indicated by the events related to the Battle of Beroia discussed earlier. Yet such groups could not have organized a raid like the one in 1068 on their own. It therefore seems that this should be regarded as the first Cuman raid on Hungary.

The events of 1071 are a different story. The direction of the raid (the southern counties of Arpadian Hungary were attacked), as well as the indirect involvement of the Byzantine duke of Belgrade seem to suggest that it was indeed the Pechenegs, who had been living in the Byzantine Balkans for 25 years, who were behind the raid. The attack and the resultant retaliatory action taken by King Solomon were probably the last clashes between the Pechenegs and Hungarians noted by historical sources.

However, some researchers hold a different opinion. They point to the events of the 108os, when the Cuman chief (dux Cunorum) Kutesk, allied with the deposed King Solomon, invaded Hungary. ${ }^{171}$ These events should be dated to 1084-1086. After some initial successes, the attackers were defeated by King Ladislaus I, who also recovered the booty they had taken, and Solomon and Kutesk were forced to flee. Based on a broad interpretation of the ethnonym Cuni, it is assumed that among the allies of the victorious king were the Pechenegs. ${ }^{12}$ However, the grounds for this identification are even weaker than in the case of the raid of 1068. There is no source that could connect the military expedition organized by Solomon and Kutesk with the Pechenegs, not even in some distorted form. Meanwhile, in the Chronicle Composition we can find an account of the expedition to the Balkans in spring 1087, also described by Anna Komnena. The Hungarian literary tradition confirms the participation of Solomon and his allies the Cuni. ${ }^{173}$

Relations between the Pechenegs and Arpadian Hungary did not manifest themselves solely in armed conflicts. It would be hard to consider the plundering raids on Hungary organized by the Pechenegs to have been extremely bothersome since, as we have seen, only two such raids are confirmed to have taken

171 Chr.Hung., 408-409; Jo.Thur., § 395-396 (p. 115).

172 Makk 1999, 77; Meško 2013, 195; Berend, Urbańczyk, Wiszewski 2013, 233.

173 Chr.Hung., 409-410; Jo.Thur., § 395 (p. 115). 
place in the 11th century. Another equally important aspect of the relations between the two nations was Pecheneg settlement in Arpadian Hungary. The aforementioned Thonuzoba most likely led one of the first groups of Pechenegs to leave the steppe and find safe haven in Hungary. This phenomenon intensified in the 11th century. The Hungarian literary tradition dates a very intensive process of immigration, involving numerous European peoples, to the reigns of Géza (972-997) and Stephen I (997-1038). ${ }^{174}$ The Pechenegs (Bessi) are listed among the peoples who settled on the territory of the Kingdom of Hungary. This story, at least in part, appears to be an anachronism, but in this case it may speak to a truth. During the reign of Stephen I, some Pechenegs may have sought shelter in Hungary after the defeats suffered in battles with the Uzes and the Rus. This process could even have intensified in the first decades of the 11th century. This migration most likely ended by the mid-12th century. It cannot be ruled out that the last Pechenegs arrived in Hungary with the Cumans led by Tatar. ${ }^{175}$

The first Arpads readily welcomed immigrants from foreign ethnic groups. Libellus de institutione morum [A Manual on Moral Formation], attributed to King Stephen I, includes the proclamation of an open 'immigration policy'. In the text, the ruler instructed his son that guests (hospites), namely new settlers, should be supported and treated with respect to make them more willing to settle in the Arpadian Kingdom, as incomers from different lands brought with them various traditions and skills, which strengthened the country. ${ }^{176}$ Even if these statements were not actually formulated by Stephen I himself, it seems that they accurately illustrate the approach towards immigrants adopted by this ruler and by the Arpad dynasty as a whole. Newcomers were treated as a source of strength for the Hungarian monarchy; by offering safe haven to refugees, Hungarian rulers benefited from this foreign element, which was fully under their control and whose members provided their services in the economy and on the battlefield.

In all probability, the Pechenegs also benefitted from this policy. Their migration to Hungary was actually a gradual influx of relatively small groups over a long, nearly 200-year period. Therefore, it was relatively easy to achieve their full political subordination and social integration. Apart from the Pechenegs' acting against King Solomon by supporting Prince Géza, a pretender to the throne, there is no information indicating any other attempts made to revolt

174 Chr.Hung. Cf. Berend 2001, 104.

175 Cf. above.

176 Libellus, 624-625. Cf. Berend 2001, 40. 
against the monarch. ${ }^{177}$ This fact seems to prove that the Arpads' policy was successful.

It is difficult to determine the number of the Pechenegs living in Hungary. Onomastic data seems to suggest that prior to the arrival of the Cumans, the Pechenegs may have been the most numerous group of settlers of foreign ethnicity. ${ }^{178}$ However, the nature of our sources calls for caution. Apart from the name of the given settlement associated with the Pechenegs, we often know nothing else about this place, its population, or it inhabitants. Moreover, the diplomatic sources from the 13th and 14th centuries that provide the onomastic material available to us sometimes indicate that during the drafting of these documents, the settlements mentioned were abandoned. ${ }^{179}$ Finally, we should bear in mind that while toponyms related to the Pechenegs are relatively numerous, there is no analogous data from Hungary concerning the Uzes-Torks. The fact that a major migration of Uzes-Torks to the Arpadian Kingdom very likely began in the latter half of the 11th century, and may have converged with a migration of the Pechenegs, gives us grounds to assume that the Pechenegs were over-represented in onomastic materials at the expense of the Uzes.

Pecheneg settlements were scattered over large sections of the Kingdom of Hungary, but were centred in its western and central parts. Along Hungary's western frontier, Pecheneg settlements are confirmed to have existed on the Leitha, south and east of Lake Neusiedl (Neusiedler See/Fertö), and along the lower and middle Rába (the counties [comitatus] of Moson, Sopron, Raab-Györ, Vas, Veszprém and Zala). ${ }^{180}$ In terms the north-west border region, Pecheneg settlements were located mostly in what is today Slovakia. We can find them north of Esztergom, and on the upper Sikenica (a tributary of the Hron), the upper Hron, the lower Žitava, the upper Nitra, and the middle Váh (in the counties of Hont, Bars, Komárom, Nitra, and Trenčín). ${ }^{181}$ The sites of six or seven Pecheneg villages have been confirmed on Žitný Ostrov (Csállóköz, or Great Rye Island) on the Danube (Bratislava/Pozsony county). ${ }^{182}$ There were

177 Cf. below.

178 Göckenjan 1972, 237-238. Göckenjan devised a list of places related to the nomadic peoples coming from the east, and it turned out that Pecheneg toponyms were the most numerous.

179 Göckenjan 1972, 100, 101, 109; Oţa, 2014, 33.

180 Rasovskii 1933, 20-24 (however, this researcher's identifications raise doubts because he often considers as Pecheneg the settlements inhabited by archers (sagitarii) whose ethnicity is undetermined in the sources); Györffy 199o, 124-129; Göckenjan 1972, 99-102.

181 Rasovskii 1933, 25-26; Györffy 199o, 156-158; Göckenjan 1972, 111-112; Marek 2003, 196-202, 204-206.

182 Rasovskii 1933, 26-27; Györffy 199o, 155-156; Göckenjan 1972, 112-113; Marek 2003, 202-204. 
also Pecheneg settlements in the northern border region of the Kingdom of Hungary by the river Sajó and its tributary, the Bodva (Borsod county). ${ }^{183}$ In Transylvania, major Pecheneg settlements were located near those of other ethnic groups, forming a defensive buffer on the eastern border of the Arpadian Kingdom. The Pechenegs also lived alongside Vlachs and Székelys in an area called Silva Blacorum et Bissenorum in the Middle Ages, located in the Cód/ Zoodt river valley. ${ }^{184}$ Pecheneg villages were likewise located west of Maros Vásárhely/Târgu Mures and west of Gyulafejérvár/Alba Iulia (south-eastern part of Bihar county, and the counties of Haromszék, Nagyküküllö, Csik and Kézdiszék). ${ }^{185}$ Finally, in the Kingdom of Hungary's southern border region, it has been confirmed that Pechenegs settled in the area between the middle and lower Drava and the Danube, as well as between the Danube and the lower Sava (counties of Somogy, Bács, Bodrog, Baranya, and Valkó). ${ }^{186}$ It cannot be ruled out that some settlements located in the area of Syrmia/Szerém/Sremska Mitrovica could have been inhabited by the Pechenegs who until 1181 served as Byzantine border guards. After this area was conquered by Béla III, they entered the service of the King of Hungary. ${ }^{187}$

Dense Pecheneg settlement is also confirmed in areas located far from Hungary's borders. We find these settlements by the Sárvíz River (in southern Fejér county and northern Tolna county), ${ }^{188}$ by the Tisza and its middle tributaries (the counties of Heves, Borsod, and Bihar), ${ }^{189}$ and finally between the Tisza and the Danube (the counties of Pilis and Pest). ${ }^{190}$ According to diplomatic sources, there were 34 settlements on the Sárvíz River, making it the largest concentration of Pecheneg settlements in all of Hungary.191

We can assume that the Pecheneg settlers in the Arpadian Kingdom were mainly engaged in military service. The location of their settlements seems to indicate that they served in the guard units defending border areas. Some also defended the roads leading to the border used by the military. Another duty of the Pechenegs was to provide contingents of light cavalry armed with bows. ${ }^{192}$

\footnotetext{
183 Rasovskii 1933, 27-28; Györffy 199o, 159-16o; Göckenjan 1972, 109.

184 Györffy 1990, 165-166; Göckenjan 1972, 106.

185 Rasovskii 1933, 30; Györffy 1990, 166-167; Göckenjan 1972, 106-107.

186 Rasovskii 1933, 31-32; Györffy 199o, 129-135, 152-153; Göckenjan 1972, 102-105.

187 Rasovskii 1933, 31; Göckenjan 1972, 104.

188 Rasovskii 1933, 39; Györffy 1990, 136-152; Göckenjan 1972, 105; Pálóczi-Horváth 1989, 32.

189 Rasovskii 1933, 40; Györffy 1990, 158-159; Göckenjan 1972, 107-109; Pálóczi-Horváth 1989, 32.

190 Györffy 1990, 153-154; Göckenjan 1972, 105-106.

191 Györffy 1971, 200; Göckenjan 1972, 105; Pálóczi-Horváth 1989, 36; Hatházi 1992-1995, 223-243.

192 Rasovskii 1933, 44; Göckenjan 1972, 113-114.
} 
The role of the former nomads who settled in the country's interior must have differed somewhat. It is assumed that their dense settlement in the area of the Sárvíz and Lake Balaton resulted from their role in defending Fehérvár, an early royal residence of the Arpad dynasty. ${ }^{193}$ The Pechenegs from this area also provided cavalry contingents to support military expeditions organized by Hungarian rulers. According to estimates made by Hansgerd Göckenjan, nomads from the counties of Fejér and Tolna were capable of equipping 400 to 600 mounted archers, $2 / 3$ of which (200-30o riders) took part in expeditions led by Hungarian monarchs. ${ }^{194}$ Apart from their customary military duties, the Pechenegs who lived on the middle Tisza were also said to breed horses for the army. ${ }^{195}$ Another task that some Pechenegs performed in Hungary was collecting duty for the Hungarian rulers and controlling sailing on the Danube. ${ }^{196}$

The first instances when Pechenegs fought for Arpad monarchs are believed to have happened in the late 1oth century. In 997, they supposedly reinforced the troops of Stephen I while he was fighting to put down an insurrection of Koppány. ${ }^{197}$ Their participation in efforts to repel the invasion of Emperor Henry III (in 1051) is much better substantiated. ${ }^{198}$ In addition, they served in the army of Stephen II when he fought against Ladislaus, Duke of Bohemia (in 1116). ${ }^{199}$ They could also be found in the army of Géza II (1141-1162) during his conflict with Henry, Duke of Austria (in 1146), when they fought in the vanguard, suffering significant loses and losing two of their commanders (comites). ${ }^{200}$ Géza II used the Pechenegs as expedition troops sent beyond the borders of the kingdom. In 115o, the Pechenegs also supported the Serbian revolt against Byzantium. ${ }^{201}$

The Pechenegs usually acted as scouts in the military expeditions of Hungarian rulers, and were skilled in guerrilla warfare. In pitched battles they were less effective in combat. Hungarian chroniclers complained constantly about their cowardice, ${ }^{202}$ but these complaints are probably unjustified. In

\footnotetext{
193 Rasovskii 1933, 39.

194 Göckenjan 1972, 105, 19 (note 176). Göckenjan relies on estimates concerning the Székelys made by György Györffy.

195 Göckenjan 1972, 110.

196 Göckenjan 1972, 105-106, 112-113.

197 Györffy 1971, 209; 1988, 100.

198 Chr.Hung., 348-349; Jo.Thur., § 310-311 (p. 91). Cf. Rasovskii 21, 44; Göckenjan 1972, 98.

199 Chr.Hung., 436; Jo.Thur., § 430 (p. 125). Cf. Rasovskii, 44-45; Pálóczi-Horváth 1989, 30.

200 Chr.Hung., 456; Jo.Thur., $\S 454$ (p. 132); Ott.Fr.-Rah., I 33 (p. 52). Cf. Rasovskii 1933, 45; Pálóczi-Horváth 1989, 30-31.

201 Io.Cinn., III 8 (p. 107); Brand 1976, 86. Cf. Rasovskii 1933, 45.

202 Chr.Hung., 436; Jo.Thur., $§ 430$ (p. 125): Bisseni atque Syculi vilissimi usque ad castrum regis absque vulnere fugierunt. Chr.Hung., 456; Jo.Thur., § 454 (p. 132). Bisseni vero
} 
direct confrontations with heavily-armed formations, light cavalry was generally ineffective, so after firing upon the enemy, the Pechenegs usually pulled back. Moreover, as has been noted, there is no evidence of any disloyalty toward the Arpad dynasty by the Pechenegs. In this respect, their behaviour contrasts with that of their fellow tribesmen who settled on the territory of the Byzantine Empire. Their siding with Géza I in his conflict with Solomon (in 1074), even though this clearly meant acting against the reigning monarch, was in fact a choice to choose one side in a dynastic dispute. The stance taken by the nomads here was probably no different than the position adopted by many other subjects of the Arpads. Like other supporters of the pretender, the Pechenegs hoped to be granted certain privileges. For this reason, they swore to put an end to Solomon's raids and prevent carrying them out beyond Moson and Pozsony counties. However, they could not keep this promise. They were defeated and many of them drowned in Lake Neusiedl, while others, including their leader Zultan, managed to flee. ${ }^{203}$

These events bring to mind the question of the legal status of the Pechenegs in Hungary. The nature of their migration to the territory of the Arpadian Kingdom seems to rule out the existence of some unified organization the nomads together, which means it was impossible for all newcomers to be granted the same rights. Unlike the influx of the Cumans, ${ }^{204}$ usually dated to 1239, the Pechenegs did not enter the Hungarian territory in one large group, but rather in many small groups, which meant that each one may have been settled under different conditions. Apart from the Pechenegs who voluntarily moved to lands belonging to Hungary and began to serve its rulers, there may have also been some Pecheneg captives who were settled against their will. It had been proven that in the counties of Pest and Pilis there were Pecheneg villages whose inhabitants grew wine grapes. This circumstance suggests that they may have been the descendants of captives who were among the group of serfs obliged to perform specific services to the court. ${ }^{205}$ Their status was most probably different than that of the nomadic groups which offered their military skills to the monarch upon their arrival in Hungary. This type of service meant that they had strong ties with the ruler, who took care of them and granted them separate rights in exchange for fulfilling military duties. It is usually assumed that the Pechenegs who settled in the basin of the Sárvíz

pessimi et Siculi vilissimi omnes pariter fugierunt sicut oves a lupis, qui more solito preibant agmina Hungarorum.

203 Chr.Hung., 395-396; Jo.Thur., § 378-379 (p. 110). Cf. Rasovskii 1933, 44.

204 Cf. Pálóczi-Horváth 1989, 47-50; Berend 2001, 68-73, 87-93, 2001a, 103-104.

205 Göckenjan 1972, 105. 
(in Fejér and Tolna counties) formed a community which enjoyed significant autonomy. Its members held periodical meetings headed by a comes, a descendent of Pecheneg steppe-dwellers. This independence continued until the 14th century, when during the reign of Louis I (1342-1382), the local Pecheneg elites became part of the nobility, though they remained under the judicial jurisdiction of the župan of Fejér. ${ }^{206}$

Nevertheless, this does not necessarily mean that all groups of military settlers enjoyed a similar level of independence. This seems to be indicated by the unfulfilled aspirations of the Pechenegs led by Zultan. For immigrants from the steppe, military service to crown was a guarantee of personal freedom and a special legal status, but with time, as the social integration of successive generations of the Pechenegs progressed, their community became less cohesive. The descendants of the elites and those of common nomads went their separate ways. The first became noblemen, whereas the latter loss their special status and became ordinary subjects. ${ }^{207}$

The social integration of the Pechenegs in the Hungarian Kingdom must have been accompanied by cultural assimilation. However, this process was not uniform. Acculturation was most certainly faster in the case of nomads who settled in areas where the natural conditions differed significantly from those of the steppe and those who were entrusted with tasks that had little in common with their former lifestyle. The Pechenegs from the counties of Pest and Pilis, for example, were bound to the land and most likely quickly broke with their old traditions. Likewise, regardless of the activities carried out by the new settlers, cultural change was much more rapid in the upland and mountainous areas of Transylvania and Slovakia than on the vast plains of Alföld, which in many ways resembled the steppe. Yet rapid cultural assimilation was not always in the interest of the Hungarian rulers, who knew it would result in a loss of fighting skills and a decline in some forms of economic activity (such as herding), the very reasons why the Arpads had readily welcomed the Pecheneg hospites and why they continued to value their presence.

Cultural change was accelerated due to strong pressures to Christianize the nomads, especially during and after the reign of Stephen I. One of its victims was said to have been Thonuzoba. He refused to be baptized, so the Hungarian ruler ordered that he and his wife be buried alive. ${ }^{208}$ Even though the credibility of this story is sometimes questioned, it is a very good illustration of the extremely harsh, not to say cruel evangelization methods practised by

\footnotetext{
206 Györffy 1990, 136-152; 1971, 200; Göckenjan 1972, 105; Pálóczi-Horváth 1989, 33; Berend, Urbańczyk, Wiszewski 2013, 471.

207 Pálóczi-Horváth 1972, 33; Oţa, 2014, 43-44.

208 G.Ung., 116-117. Urkund, the son of Thonuzoba, was baptized.
} 
King Stephen. ${ }^{209}$ The fate of Thonuzoba most probably reflects the choice that many representatives of the Pecheneg elites faced at that time, especially those close to the royal court. Christianization, a process which by its very nature was extremely slow and extended over several generations, surely did not mean that old traditions were immediately and completely rejected. However, because the Arpad rulers were strongly involved in conversion efforts and vigorously supported the Hungarian church, Christianization was most probably one of the main tools used to assimilate and integrate the Pechenegs. Their native religious practices did not survive the 11th century. ${ }^{210}$ Sources dating back to the 13th century no longer present the Pechenegs as pagans, whereas in the Late Middle Ages we find cases of strong relations between persons of Pecheneg descent and the Hungarian church. ${ }^{211}$

The descendants of Pechenegs who were fully integrated both socially and culturally were appointed to the highest state positions in Hungary. For instance, Magnificus Paulus Byssenus de Eorghede served as the Ban of Dalmatia, Croatia and Slovenia in the years $1404-1406 .{ }^{212}$ However, the price for such a spectacular career was a complete break with one's former steppe traditions, of which a feint reminder were ethnic accents in official titles.

\subsection{The Pechenegs in Rus'}

Evidence for the Pechenegs' presence in the lands ruled by the Rurik dynasty can be found in chronicles as well as through onomastic research, although the latter is based on rather sparse material when compared to that of Hungary. As we have already seen, starting from the latter half of the 11th century, Rus' chroniclers usually mentioned the Pechenegs along with two other steppe groups, the Torks and the Berendei. In 1146, the chronicles provide the first account of the so-called Cherni Klobuci, ${ }^{213}$ a community of steppedwellers from southern Rus' who lived mainly in the principalities of Kiev and Pereiaslavl. ${ }^{214}$ Without a doubt this community was comprised not only of the Torks, Berendei and several smaller nomadic groups of Turkic origin, but also

\footnotetext{
209 Berend, Laszlovszky, Szakács 2007, 333-335, 344-346; Berend 2013, 261-269.

210 Pálóczi-Horváth 1989, 38; Berend 2001, 56.

211 In 1373, castellan Johannes Beseny de Nezda obtained permission to build a monastery. Cf. Györffy 1990, 134; Berend 2001, 56-57.

212 Rasovskii 1933, 50.

213 Ip.Let., col. 323.

214 For more on the Cherni Klobuci: Rasovskii 1927, 93-109; 1933, 1-66; 1940, 369-378; Pletneva 1973; Nagrodzka-Majchrzyk 1985; Golden 1996, 97-107; Kijas 2007, 145-156; Morgunov 2010, 62-75.
} 
of Pechenegs. ${ }^{215}$ It is not entirely clear how this community was organized. The name 'Cherni Kolobuci' translates as 'black hats' and refers to the pointed, cone-shaped headgear worn by them. The adjective 'black', however, may indicate the subservient and subordinate, or even slave-like status of the Cherni Klobuci. ${ }^{216}$ Each group belonging to the Cherni Klobuci had its own leader and, as can be seen from archeological materials and written sources, some form of social stratification. ${ }^{217}$ Notwithstanding these facts, they were initially subordinated entirely to the Rus' princes' authority and did not have the right to carry out their own armed expeditions. ${ }^{218}$ The Cherni Klobuci's obligations were limited to military service, which consisted in protecting the borders of Rus', and providing contingents of cavalry during armed expeditions. ${ }^{219}$

The political break-up of Rus', and especially the struggle for control of Kiev, provided a road to emancipation for the steppe-dwellers. As a prized and relatively numerous military force, ${ }^{220}$ the Cherni Klobuci constituted which they leveraged to gain advantageous concessions and privileges while offering in return to support individual pretenders to the Kievan throne. D. Rasovskii noted that they usually supported those Rurikids who descended from the elder sons of Vladimir Monomakh (d. 1125) and ruled the Rus' principalities located on the right bank of the Dnieper River. This was motivated by the Cherni Klobuci's animosity towards the Cumans who provided military assistance to the rulers of the left-bank principalities, i.e. Chernigov and Suzdal. In the second half of the 12th century, however, the Cherni Klobuci groups were so prominent that each Rus' prince had to have a somewhat stable relation with them in order to preserve his authority in Kiev. ${ }^{221}$ Their elites enjoyed a special position, especially the khans of the Cherni Klobuci who were often known by name. The fact that they were entrusted with the management of the strongholds inhabited not only by Turkic but also by Slavic people proves that they had considerable leverage. ${ }^{22}$ The relations between those two ethnic

215 This is clearly indicated by entries in the Hypatian chronicle: Ip.Let., AM 6659 (1151), col. 427-428; AM 667 (1162), col. 517; AM 6677 (1169), col. 533. Cf. Nagrodzka-Majchrzyk 1985, 38-41, 67; Golden 1996, 101-104; Morgunov 2010, 72.

216 Rasovskii 1933, 16 (note 85); Nagrodzka-Majchrzyk 1985, 67-68; Golden 1996, 104-107.

217 The Hypatian chronicle (Ip.Let., AM 6688 (1180), col. 622) mentions the 'better' Cherni Klobuci. Cf. Pletneva 1973, 12-17.

218 Nagrodzka-Majchrzyk 1985, 77.

219 Rasovskii 1927, 93-99; 1933, 57-58.

220 Dimitri Rasovskii estimated the number of the Cherni Klobuci, together with their families, at around 100,000 $(1933,58)$.

221 Rasovskii 1927, 99-102; 1940, 372-377; Kijas 2007, 151.

222 Rasovskii 1933, 6o. 
groups were rarely hostile. The Slavic farmers had become accustomed to the proximity of the nomads whom they called 'our pagans.' ${ }^{223}$

The Cherni Klobuci's main dwellings sprawled from south of Kiev to the Ros' River. The Torchesk stronghold, the heart of their settlement, had been located there since the end of the 11th century. Six other strongholds, which belonged to the nomads serving the Kievan princes, were situated by the Ruta River, the left tributary of the Ros' River. ${ }^{224}$ The Rus' Pechenegs, who were probably considered to be a part of the Cherni Klobuci, inhabited a narrow strip of Kievan land between the Dnieper River, the upper course of the Karan' and the Alta River. In 1142, the Rus' chronicles recorded the Pechenegs under command of Lazar, holder of the Sakov stronghold. ${ }^{225}$ Eight years later, they mentioned that the Turpei a little-known ethnic group, lived in the same area and because of that they were usually associated with the Pechenegs. ${ }^{226}$ In the Principality of Pereiaslav, the Cherni Klobuci's dwellings were spread south of the rampart surrounding its capital city. 227

It seems that the Pechenegs did not have a very prominent status among the Cherni Klobuci. Rus' sources portray to a greater extent the role of the Torks and Berendei. What is significant is that the name of the main Cherni Klobuci settlement clearly referred to the Torks. Moreover, steppe-dwellers arrived in Rus' in greater numbers after the death of Iaroslav the Wise, ca. 106o, ${ }^{228}$ when the main groups of Pechenegs had already left the Black Sea steppe. The fact that the Rus' chronicles suddenly mention them after more than a half a century of silence is particularly puzzling. Additionally, since the end of the 11th century, the Pechenegs had been mentioned usually together with the Torks-Uzes. This raises the question as to whether these are the people who, according to Constantine viI Porphyrogenitus, were separated from this ethnic group in the late 9th century and lived among the Uzes. ${ }^{229}$ The same group is also mentioned by Ahmad ibn Fadlān, who met some poverty-stricken Pechenegs while he was wandering through the Caspian steppes. ${ }^{230}$ However, it is difficult to believe they survived as a distinct group for 200 years while living under the leadership of the Torks-Uzes. Considering the scarcity of sources, these developments must be treated as a difficult to prove hypothesis. Nevertheless, all of

\footnotetext{
223 Nagrodzka-Majchrzyk 1985, 134.

224 Rasovskii 1933, 53-55.

225 Ip.Let., AM 665 O (1142), col. 311.

226 Rasovskii 1933, 14-15, 59; Morgunov 2010, 68.

227 Rasovskii 1933, 59-6o.

228 Morgunov 2010, 68.

229 DAI, XXXVII 51-57 (p. 168). Cf. Chapter 3 of the present book.

230 ibn Fadlan: ibn Fadlan, 212; Zeki Validi Togan 1939, 33; Kovalevskii 1956, 130; Frye 2005, 42.
} 
the above does not change the fact that among the three main Turkic groups which comprised the Cherni Klobuci, the Pechenegs were the weakest and least numerous. As mentioned before, in the 12th century, the Rus' chronicles described at length the actions of the Torks and Berendei. The toponyms in the Ros' basin indicate, above all, the presence of the Torks-Uzes, Cumans, and even Khazars, but not the Pechenegs. ${ }^{231}$

The last reference to the Pechenegs in the chronicles comes from 1169, which leads us to assume that in the last third of the 12th century they were no longer a separate group due to the influence of the other, stronger groupings of Cherni Klobuci, which ceased to exist as a result of the Mongol invasion. Rashid al-Din was the last writer to mention them, stating that Batu Khan attacked a tribe of 'black hats' in 1240. ${ }^{232}$ Their later fate is purely a subject of hypothetical speculation. Mikhailo Hrushevski claimed that the Cherni Klobuci were forced by the Mongols to return to the steppe as their slaves. ${ }^{233}$ Other researchers have suggested that they might have survived in Rus' and later became part of the Cossack movement. ${ }^{234}$ Finally, the Cherni Klobuci are also considered by some to be the ancestors of the Karakalpaks who lived by the Aral Sea. ${ }^{235}$

The presence of the Pechenegs is confirmed by place names that appear not only on the outskirts of Kiev and Pereiaslav, but also in other regions of the old Rus'. Not far from Kolomyia in the Pokutia region there is a village called Pechenezhyn. It is difficult to say under what circumstances this village was founded. The village is sometimes associated with the arrival of groups of Pechenegs, Torks, and Berendei to the lands of Prince Vasylko of Terebovlia, who later led them to attack Polish lands, as mentioned in the chronicles. ${ }^{236}$ Pechenezhyn is believed to have been inhabited by military settlers who protected the Principality of Halych in the south from invasion by steppe-dwellers and guarded the road leading through the Iablunits'kii Pass. ${ }^{237}$ A 'Pecheneg burial mound' (mogila Pechenegi) is located on the border of Volhynia, near Zvenigorod. Dmitri. A. Rasovskii has suggested that the inhabitants of this settlement were tasked with guarding the road leading from Kiev to Hungary and securing the border between the Principality of Halych and Volhynia. ${ }^{238}$ In the vicinity of Przemyśl there was once a village called Pecheneie,, ${ }^{239}$ and

\footnotetext{
231 Morgunov 2010, 70.

232 Rasovskii 1933, 62.

233 Grushevs'kii 1905, 551.

234 Cf. Rasovskii 1933, 63; Nagrodzka-Majchrzyk 1985, 79.

235 For a critical look at such views: Golden 1996, 98-10o.

236 PVL 1, AM 66о5 (1097), col. 266. Cf. Morgunov 2010, 7 O.

237 Rasovskii 1933, 51.

238 Rasovskii 1933, 52.

239 Grushevs'kii 1905, 585; Rasovskii 1933, $5^{2}$.
} 
the village of Pecheniugi once existed near Novohrod-Siverskyi. ${ }^{240}$ The lack of additional data makes it difficult to determine the significance of these two settlements or how their inhabitants supported themselves.

The acculturation of the Turkic nomads living in Rus' did not progress smoothly. In particular, the groups belonging to the Cherni Klobuci continued to lead a nomadic lifestyle and engage in activities characteristic of nomadic life. Apart from some members of the elite who moved to Kiev, the vast majority of steppe-dwellers remained pagans. This was possible due both to the landforms and ecosystems of Rus', as its forest steppes were conducive to extensive herding, as well as to the Rurikids' policies towards these people. It was in their interest to have at their disposal an armed force whose members preserved the military prowess characteristic of nomads. Their sedentarization and cultural assimilation might have caused these advantages to disappear. ${ }^{241}$ On the other hand, the Rurik dynasty had neither the power nor the means to successfully convert nomads to Christianity in the way the Arpads did in the 11th-century in Hungary. This was especially true after Vladimir Monomakh's death, when a fierce rivalry for the Kievan throne ensued and led to frequent changes in who ruled the capital city. Finally, we can only speculate on whether the methods of the Hungarian rulers could have been adopted in Rus', which belonged to the Byzantine world, a world that was much more cautious than Latin Europe, almost to the point of passivity, in carrying out missionary activities.

\subsection{The Pechenegs under Piast Dynasty Rule (?)}

Polish historiographers for a long time held the opinion that relations between the first Piasts, especially Bolesław Chrobry, and the Pechenegs were that of good neighbours. ${ }^{242}$ In truth, they were neither good nor neighborly. In the previous chapter, the political dimension of the relations between the early Piast monarchy and the Pechenegs were analyzed in detail. It can be concluded that

\footnotetext{
240 Rasovskii 1933, 6o.

241 Rasovskii 1933, 63-64.

242 Zakrzewski 1925, 224 ('[...] Bolesław generally had a good rapport with the Pechenegs [...]'), 307; Bieniak 2010, 156 (The Pechenegs were already Chrobry's allies during St. Bruno of Querfurt's mission to the steppe-dwellers), 16o (The Pechenegs as participants of Mieszko II's expedition against the Saxons, dated to 1028 or 1030); Tyszkiewicz 2003, 37 (Mieszko I had already maintained intensive communication with the Pechenegs). Recently also: Tyszkiewicz 2014, 188. According to Tyszkiewicz, Bolesław Chrobry's influence reached as far as the Dniester and the lower Dnieper, which means it actually spanned nearly the entire area inhabited by the Pechenegs in the early 11th century.
} 
these relations were episodic and limited to their participation in Bolesław Chrobry's two expeditions to Rus' (1013 and 1018). The Pechenegs were most likely involved in them as allies of the Rus' prince Sviatopolk, who, as sources indicate, maintained political relations with the steppe-dwellers and made use their military support numerous times. However, there is no analogous data confirming the existence of any kind of formal agreement between the nomads and the first Piasts. It is often argued that the geopolitical situation supports the hypothesis of a Polish-Pecheneg alliance. The political rivalry on the Polish-Rus' border would have supposedly naturally led to an alliance of this kind. The problem here is that what should hypothetically result from a geopolitical situation is not always what actually happens. Although the geographical situation of the Pechenegs and the Byzantine Empire forced them to coexist, relations between them were always complicated and not always the result of rational motivations. Constantine Porphyrogenitus's doctrine, which postulated a special relationship with the Pechenegs, had a relatively short life, probably not much longer than the independent reign of this emperor. ${ }^{243}$ Byzantine diplomacy at times favored other partners who were more demanding, but also more predictable, as the court in Constantinople tended to perceive the Pechenegs to be a sort of a political amoeba. ${ }^{244}$ However, the Empire, which for centuries had nomads as neighbours, was forced to take them into account in its policies. It is unlikely that the same was true in the case of the Piast monarchs, as their lands bordered the areas controlled by the steppedwellers for only a very short time, i.e., in the years 1018-1031..$^{245}$

A separate question is that of the Pechenegs' presence on the lands ruled by the Piasts. This presence, as in the case of other states in Central and Eastern Europe, may have taken the form of brief armed incursions or of more permanent settlement. As mentioned in the previous chapter, the steppe-dwellers probably carried out raids in southeastern Poland. The sources also provide evidence that Pechenegs settled on Polish lands. This is indicated by a group of five toponyms, such as 'Pieczeniegi' and 'Pieczonogi', found on the left bank of the Vistula, between Kraków and Staszów. They form two clusters some 80 $\mathrm{km}$ apart. The first cluster consists of three settlements located near Miechów, north-east of Kraków. The second cluster is comprised of two villages a dozen or so kilometers apart: Pieczonogi, near Oleśnica, and Pieczonóg-Gacki, near Szydłów. ${ }^{246}$ The nature of these settlements is unclear. Polish researchers have

\footnotetext{
243 Cf. Chapter 5.4.

244 Cf. the statements made by John Mauropous cited in the first part of this chapter.

245 Cf. the discussion in Chapter 6.1.

246 Rymut 1967, 123-124; Modrzewska 1969, 365; 1984, 32-34; Tryjarski 1975a, 616.
} 
sometimes claimed that these were cases of military settlement. ${ }^{247}$ Such speculation is difficult to confirm or disprove. It is more probable, though still not proven, that the villages were inhabited by captives who performed menial labour. This thesis is supported by the results of research carried out on the cemetery in Gorysławice, near Wiślica, i.e., at a site located in between the two groups of Pecheneg-derived toponyms. ${ }^{248}$ The graves found there date back to the latter half of the 11th and early 12th century. The human remains discovered there have anthropological features characteristic of so-called Eurasian types. Out of 20 skulls selected for analysis, 17 individuals show characteristics of a caucasoid-mongoloid racial mix and one of the mongoloid race. However, the features of this burial site do not differ from those of burial site found in other 11th- and 12th-century cemeteries in Małopolska, and no traces of Eastern, steppe origns were found. ${ }^{249}$ Witold Świętosławski has also pointed out that steppe vegetation occurs in the area around Gorysławice. ${ }^{250}$ Taking into consideration the above facts, one can assume that former nomads settled on the Nida River near Wiślica, but that these were not military settlers, but rather people living in servitude who engaged in herding.

There is no hard data indicating the Pechenegs maintained a long-term presence among the troops of the first Piasts (or rather of Bolesław Chrobry). As mentioned above, Thietmar's writings do not confirm such a presence. During both expeditions to Rus', the steppe-dwellers temporarily served as mercenaries, whose abilities the Polish ruler did not assess highly. The occasionally discovery in Poland of elements of military equipment of foreign, eastern origin, such as a 'snaffle bit' with a rigid mouth piece, ${ }^{251}$ is not evidence that Pecheneg warriors served the Piasts. Weapons changed hands as loot and war trophies. The same is true of riding tack when a horse was captured. Today researchers challenge the view that a bit with a rigid mouth pieces unambiguously identifies the remains as belonging to the Pechenegs. This element of equestrian

247 Łowmiański 1975, 47-48. 'Located along the left bank of the Vistula, the Pechenegs' settlements had to [sic! - A.P.] help contain the invasion of people from their own ethnic group'.

248 Recently Witold Świętosławski wrote about them (2006a, 120-121).

249 Charzewska 1963, 199-211. In a study published in the same volume, Wojciech Szymański, concludes that the cemetery in Gorysławice was established by the inhabitants of Wiślica in the latter half of the 11th century, and was in use until the beginning of the next century. The researcher found no foreign ethnic characteristics among the deceased there. Cf. Szymański 1963, 190-191.

250 Świętosławski 2006a, 121 (note 17).

251 Wołoszyn 2004, 258-259; Kollinger 2014, 396. 
accoutrement is most certainly of steppe origin, and could have been used by the Pechenegs, but not necessarily only by them..$^{252}$

The modest available source data suggests that, as in the case of political relations, the presence of the Pechenegs on Polish lands was very limited. Although they probably resided in the lands of the Piasts, their role - especially in comparison with those members of their ethnic group who settled in Byzantium, Hungary, and Rus' - was minor.

252 Cf. Armarchuk 2006, 40-41; Spinei 20o9, 294-295. 